$(200)$
T6tr
No. 559

\title{
Reconnaissance for uranium in asphalt-bearing rocks in the western states
}

By W. J. Hail, Jr.

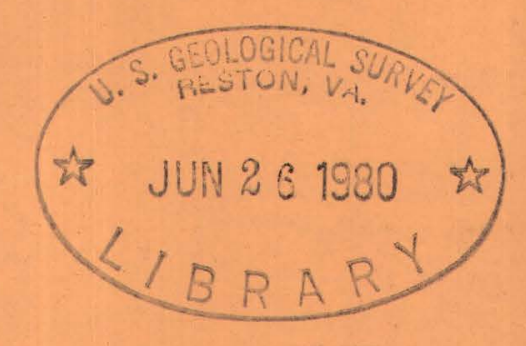

Trace Elements Investigations Report 559

UNITED STATES DEPARTMENT OF THE INTERIOR GEOLOGICAL SURVEY 
This document consists of 49 pages. Series A

UNITED STATES DEPARTMENT OF THE INTERIOR

GEOLOGICAL SURVEY

RECONNAISSANCE FOR URANIUM IN ASPHALT-BEARING ROCKS

IN THE WESTERN STATES

By

W. J. Hail, Jr 。

September 1955

Trace Elements Investigations Report 559

This preliminary report is distributed without editorial and technical review for conformity with official standards and nomenclature. It is not for public inspection or quotation.

* This report concerns work done on behalf of the Division of Raw Materials of the U. S. Atomic Energy Commission. 
USGS - TEI-559

GEOLOGY AND MINERALOGY

Distribution (Series A)

Argonne National Laboratory .

No. of copies

Atomic Energy Commission, Washington . . . . 2

Division of Raw Materials, Albuquerque . . . . . . 1

Division of Raw Materials, Butte . . . . . . . . 1

Division of Raw Materials, Casper . . . . . . . . 1

Division of Raw Materials, Denver . . . . . . . 1

Division of Raw Materials, Hot Springs . . . . . . 1

Division of Raw Materials, Ishpeming . . . . . . . 1

Division of Raw Materials, Phoenix . . . . . . . 1

Division of Raw Materials, St. George . . . . . . 1

Division of Raw Materials, Salt Lake City . . . . . 1

Division of Raw Materials, Washington . . . . . 3

Exploration Division, Grand Junction Operations Office . 1

Grand Junction Operations Office . . . . . . . . 1

Technical Information Service, Oak Ridge . . . . . 6

U. S. Geological Survey:

Fuels Branch, Washington. . . . . . . . . . . 5

Geochemistry and Petrology Branch, Washington . . . 1

Geophysics Branch, Washington. . . . . . . . . 1

Mineral Classification Branch, Washington . . . . . 2

Mineral Deposits Branch, Washington . . . . . . . 2

E. H. Bailey, Menlo Park. . . . . . . . . . 1

A. L. Brokaw, Grand Junction . . . . . . . . 1

N. M. Denson, Denver . . . . . . . . . . 2

R. L. Griggs, Albuquerque . . . . . . . . . 1

M. R. Klepper, Spokane . . . . . . . . . . . 1

A. H. Koschmann, Denver . . . . . . . . . . 1

J. D. Love, Laramie . . . . . . . . . . . 1

L. R. Page, Washington . . . . . . . . . . 1

Q. D. Singewald, Beltsville . . . . . . . . . 1

A. E. Weissenborn, Spokane . . . . . . . . 1

TEPCO, Denver . . . . . . . . . . . . 2

TEPCO, RPS, Washington (including master) . . . $\frac{2}{49}$ 


\section{CONTENTS}

$\underline{\text { Page }}$

Abstract . . . . . . . . . . . . . . . 5

Introduction . . . . . . . . . . . . . 6

Field work . . . . . . . . . . . . . . . . 9

Summary of results of the investigation . . . . . . 12

Origin of the uranium . . . . . . . . . . 16

Description of deposits . . . . . . . . . . . 18

California . . . . . . . . . . . . . 18

Point Arena area . . . . . . . . . . 19

Santa Cruz area . . . . . . . . . 20

Chalone Creek and San Lorenzo Creek areas . 21

San Ardo area . . . . . . . . . . . . 22

Bradley area . . . . . . . . . . . 22

McKittrick area . . . . . . . . . . 23

Edna area . . . . . . . . . . . . 24

Casmalia area. . . . . . . . . . 26

Los Alamos area . . . . . . . . . . . 27

Other areas . . . . . . . . . . . 28

Utah . . . . . . . . . . . . . 30

Vernal area. . . . . . . . . . 30

Sunnyside area . . . . . . . . . . 32

Other areas. . . . . . . . . . . . 33

Wyoming . . . . . . . . . . . . . . 34

Muddy Creek area . . . . . . . . . 34

Jameson Ranch area . . . . . . . . 35

Montana . . . . . . . . . . . . . 36

Red Dome area . . . . . . . . . 36

New Mexico . . . . . . . . . . . . . . 37

Santa Rosa area . . . . . . . . . 37

Texas . . . . . . . . . . . . 38

Uvalde area . . . . . . . . . 38

Oklahoma . . . . . . . . . . . . . 39

Sulphur area . . . . . . . . . 39

Cameron area. . . . . . . . . . 40

Other areas . . . . . . . . . . . 41

Missouri . . . . . . . . . . . . . 44

Ellis area . . . . . . . . . . . 44

Other areas . . . . . . . . . . 45

Literature cited . . . . . . . . . . . 47 


\section{ILLUSTRATIONS}

Figure 1. Map of western United States showing areas

$\underline{\text { Page }}$ examined for uranium in asphalt-bearing rocks. . . . . . . . . . . . .

2. Geologic map of part of the Edna area, San Luis Obispo County, California . . . . . . 25

\section{TABLES}

Table 1. Summary of asphalt-bearing formations sampled for uranium in the western states . . . . 10

2. Summary of data from areas examined for uranium in asphalt-bearing rocks . . . . . . . 14 
RECONNAISSANCE FOR URANIUM IN ASPHALT-BEARING ROCKS IN

THE WESTERN STATES

By W. J.Hail, Jr.

ABSTRACT

An appraisal of asphalt-bearing rocks as potential sources of uranium was made during 1953 and 1954 by examining deposits in 45 areas in California, Utah, Wyoming, Montana, New Mexico, Texas, Oklahoma, and Missouri. A total of 202 samples from the se areas was analyzed for uranium. The oldest rocks sampled are Ordovician in age, and the youngest are Recent. Although none of the deposits are of value at this time as a source of uranium, some of the deposits may constitute a low grade uranium resource whose recovery will depend upon the primary use to which the asphalt is placed.

Significant amounts of uranium in the ash of the extracted oil were found in samples from 7 of the 45 areas examined. The se areas are: Chalone Creek, McKittrick, Edna, and Los Alamos areas, California; Vernal area, Utah; Sulphur area, Oklahoma; and the Ellis area, Missouri. The average uranium content of samples from these seven areas ranges from 0.028 to 0.376 percent in the ash of the extracted oil. All except the Chalone Creek area contain large estimated reserves of asphaltbearing rock, ranging from 15,000,000 to almost 2, 000,000, 000 tons. The average uranium content of samples from 13 additional areas ranges from 0.020 to 0.068 percent in the ash of the extracted oil. Many of these areas contain very large reserves of asphalt-bearing rocks. 
Evaluation of field data indicates that naturally occurring asphalts with a relatively high uranium content probably originated in, or migrated through, rocks that contain more than average amounts of uranium. It is believed that some of the uranium was present as an original constituent of the oil but that some uranium may have been introduced during migration of the oil.

\section{INTRODUCTION}

Field investigations and laboratory research on uranium in asphaltbearing rocks were carried on during 1953 and 1954 by the U. S. Geological Survey on behalf of the Division of Raw Materials of the U. S. Atomic Energy Commission. The results of the field investigations are presented in this report. Previous work by the Geological Survey (Erickson, Myers, and Horr, 1954) showed that the uranium content of the ash of natural asphalt and oil extracted from petrolife rous rock is significantly higher than that of crude oil, sea water, and granitic rock. This suggested the possibility that some of the numerous deposits of asphalt-bearing rock of the western United States might contain appreciable amounts of uranium. Selected deposits of asphalt-bearing rocks were examined and sampled in eight western states to evaluate this type of rock as a possible source for uranium (fig. 1). 


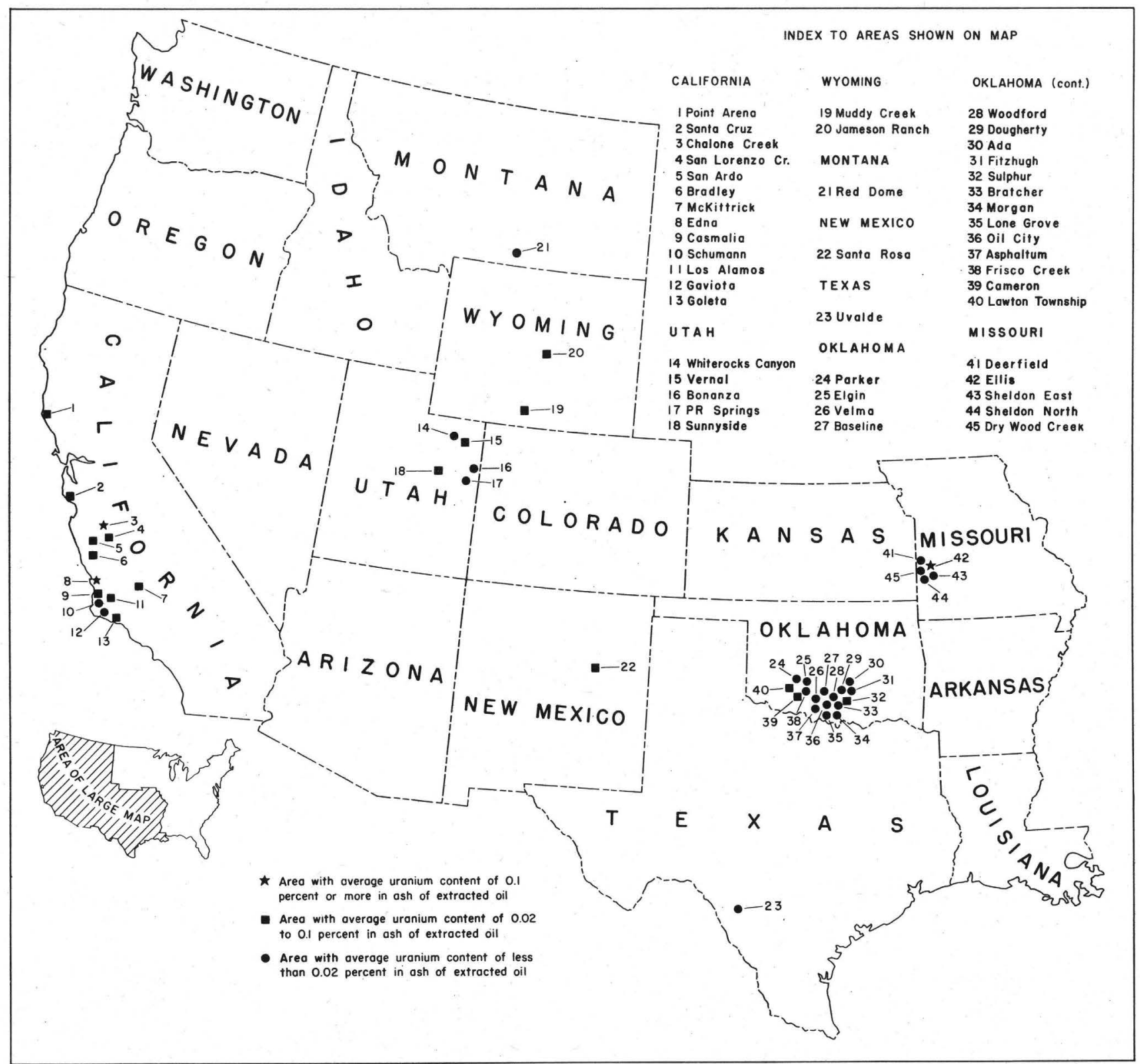

FIGURE I -MAP OF WESTERN UNITED STATES SHOWING AREAS EXAMINED FOR URANIUM IN ASPHALT-BEARING ROCKS 
Chemical analyses for uranium of several selected samples of the extracted asphalt and of the rock residue showed that the uranium is mainly concentrated as an organo-uranium complex in the asphaltic portion of the sample and not in the rock residue. Similar analyses by Erickson, Myers, and Horr (1954, p. 2215) also showed that the uranium is concentrated in the oil and not in the rock residue. Inasmuch as significant amounts of uranium occur only in the ash of the oil extracted from the host rocks, these amounts constitute only a minute fraction of the bulk sample. For example the most highly uraniferous sample collected contained 1.9 percent uranium in the ash of the extracted oil but contained only about 0.0005 percent uranium in the bulk sample. It is apparent that the importance of the se asphalt deposits as a source for uranium is in the ash of the extracted oil. Therefore, tables of sample analyses in this report show the amount of oil in the rock, the amount of ash in the oil, and the amount of uranium in the oil ash.

Descriptions of the various deposits are based on numerous published reports in addition to direct field observations. Reserve estimates of asphalt-bearing rocks, also taken from published reports, are given where available.

Results of sample analyses were furnished by A. T. Myers, C. A. Horr, and M. M. Curtis of the Geological Survey Trace Elements Denver Laboratory, whose work on laboratory research on uranium in asphaltbearing rocks will be described in a separate report.

The term asphalt-bearing rocks as used in this report designates rocks which contain any type of naturally occurring petroleum residue. 


\section{FIELD WORK}

Asphalt-bearing rocks were examined in 45 selected areas in California, Utah, Wyoming, Montana, New Mexico, Texas, Oklahoma, and Missouri. Many of the areas examined contain easily accessible deposits of asphalt-bearing rock, which have been produced commercially for asphalt, and contain reserves ranging from a few thousand to about 2,800,000,000 tons. A total of 202 representative samples from the 45 areas was analyzed for uranium and for oil content. The se samples were taken from 23 geologic formations representing rocks of

Ordovician, Pennsylvanian, Permian, Triassic, Jurassic, Cretaceous, Paleocene, Eocene, Miocene, Pliocene, Pleistocene, and Recent age. Table 1 summarizes the formations sampled.

All the rocks sampled were tested for radioactivity with a scintillation counter or Geiger counter and none was noticeably radioactive. 
Table 1.--Summary of asphalt-bearing formations sampled for uranium in the western states.

\begin{tabular}{|c|c|c|c|}
\hline State & Age & Formation & $\begin{array}{l}\text { Predominant lithology } \\
\text { of formation in } \\
\text { areas examined }\end{array}$ \\
\hline \multirow[t]{9}{*}{ California } & Recent & Alluvium & $\begin{array}{l}\text { Unconsolidated surface } \\
\text { material. }\end{array}$ \\
\hline & $\begin{array}{l}\text { Pliocene- } \\
\text { Pleistocene }\end{array}$ & Tulare fm. & $\begin{array}{l}\text { Clay, silt, sand, and } \\
\text { gravel. Gravel consists } \\
\text { of siliceous shale, chert, } \\
\text { granite and quartzite. }\end{array}$ \\
\hline & Pliocene & $\begin{array}{l}\text { Etchegoin } \\
\mathrm{fm} \text {. }\end{array}$ & $\begin{array}{l}\text { Sandstone, silty claystone, } \\
\text { and pebble conglomerate. }\end{array}$ \\
\hline & Pliocene & $\begin{array}{l}\text { Unnamed } \\
\mathrm{fm} .\end{array}$ & $\begin{array}{l}\text { Arkosic conglomerate and } \\
\text { sandstone. }\end{array}$ \\
\hline & $\begin{array}{l}\text { Miocene- } \\
\quad \text { Pliocene }\end{array}$ & Pismo fm. & $\begin{array}{l}\text { Conglomerate, arkosic } \\
\text { sandstone, diatomaceous } \\
\text { sandstone, sandy and } \\
\text { silty shale, diatomaceous } \\
\text { shale, siliceous shale, } \\
\text { and chert. }\end{array}$ \\
\hline & $\begin{array}{l}\text { Miocene- } \\
\text { Pliocene }\end{array}$ & Sisquoc $\mathrm{fm}$. & $\begin{array}{l}\text { Diatomace ous mudstone, } \\
\text { sandstone, micaceous } \\
\text { siltstone, and claystone. }\end{array}$ \\
\hline & Miocene & $\begin{array}{l}\text { Santa } \\
\text { Margarita } \\
\text { ss. }\end{array}$ & Arkosic sandstone. \\
\hline & Miocene & $\begin{array}{l}\text { Monterey } \\
\text { sh. }\end{array}$ & $\begin{array}{l}\text { Diatomace ous shale and } \\
\text { siltstone, porcelaneous } \\
\text { diatomite, siliceous } \\
\text { shale, and sandstone. }\end{array}$ \\
\hline & Miocene & Vaqueros ss. & Arkosic sandstone. \\
\hline \multirow[t]{3}{*}{ Utah } & Eocene & Uinta $\mathrm{fm}$. & $\begin{array}{l}\text { Quartzose sandstone, } \\
\text { shale, and conglomerate. }\end{array}$ \\
\hline & Eocene & $\begin{array}{l}\text { Green River } \\
\mathrm{fm} .\end{array}$ & $\begin{array}{l}\text { Sandstone, shale, minor } \\
\text { amounts of limestone. }\end{array}$ \\
\hline & Jurassic(?) & Navajo ss. & Sandstone. \\
\hline \multirow[t]{2}{*}{ Wyoming } & Paleocene & $\begin{array}{l}\text { Fort Union } \\
\text { fm. }\end{array}$ & $\begin{array}{l}\text { Sandstone, shale, and } \\
\text { conglome rate }\end{array}$ \\
\hline & Cretaceous & $\begin{array}{l}\text { Teapot ss. } \\
\text { member of } \\
\text { Mesaverde } \\
\text { fm. }\end{array}$ & Sandstone \\
\hline
\end{tabular}


Table 1.--Summary of as phalt-bearing formations sampled for uranium in the western states.--Continued

\begin{tabular}{|c|c|c|c|}
\hline State & Age & Formation & $\begin{array}{c}\text { Predominant lithology } \\
\text { of formation in } \\
\text { areas examined }\end{array}$ \\
\hline Montana & Triassic & $\begin{array}{l}\text { Chugwater } \\
\text { fm. }\end{array}$ & $\begin{array}{l}\text { Sandstone and sandy } \\
\text { shale. }\end{array}$ \\
\hline New Mexico & Triassic & $\begin{array}{l}\text { Santa Rosa } \\
\text { ss. }\end{array}$ & Sandstone and shale. \\
\hline Texas & Cretaceous & Anacacho 1s. & Limestone. \\
\hline \multirow[t]{3}{*}{ Oklahoma } & $\begin{array}{l}\text { Permian } \\
\text { Pennsylvanian }\end{array}$ & $\begin{array}{l}\text { Wichita } \mathrm{fm} \text {. } \\
\text { Ada } \mathrm{fm} \text {. }\end{array}$ & $\begin{array}{l}\text { Sandstone and shale. } \\
\text { Sandstone, conglomerate, } \\
\text { shale, and limestone. }\end{array}$ \\
\hline & Pennsylvanian & Deese $\mathrm{fm}$. & $\begin{array}{c}\text { Sand stone, conglomerate, } \\
\text { shale, and limestone. }\end{array}$ \\
\hline & $\begin{array}{l}\text { Ordovician } \\
\text { Ordovician }\end{array}$ & $\begin{array}{l}\text { Viola ls. } \\
\text { Oil Creek fm. }\end{array}$ & $\begin{array}{l}\text { Lime stone. } \\
\text { Sand stone. }\end{array}$ \\
\hline Missouri & Pennsylvanian & $\begin{array}{l}\text { Bartlesville } \\
\text { sand of } \\
\text { Cherokee } \\
\text { sh. }\end{array}$ & Sand stone. \\
\hline
\end{tabular}




\section{SUMMARY OF RESULTS OF THE INVESTIGATION}

Uranium was found in asphalt-bearing rocks in all of the 45 areas examined in average concentrations ranging from 0.001 to 0.376 percent in the ash of the extracted oil. None of the areas contains asphalt deposits of value at this time as a source of uranium. Whether any of the deposits might provide a low-grade source of uranium probably depends upon recovery methods in the utilization of the asphalt for other purposes. Table 2 briefly summarizes analytical data and other information on the asphalts from all the areas examined.

Deposits in seven of the areas yielded samples significantly high in uranium in the ash of the extracted oil. These areas, listed with the uranium content of their richest samples, are: Chalone Creek 0.50 percent U), McKittrick (0.15 percent U), Edna (1.9 percent U), and Los Alamos (0.33 percent U) areas, California; Vernal area, Utah (0.15 percent U), Sulphur area, Oklahoma (0.22 percent U); and the Ellis area, Missouri ( 0.40 percent $U)$. The average uranium content of samples from these seven areas ranges from 0.028 percent in the Vernal area to 0.376 percent in the Edna area. All of the se deposits except those in the Chalone Creek area contain large estimated reserves of asphalt-bearing rock, ranging from 15,000,000 tons to almost $2,000,000,000$ tons. The most uraniferous deposits found are in the Edna area. 
The average uranium content of samples from 13 other areas ranges from 0.020 to 0.068 percent in the ash of the extracted oil. These areas are: Point Arena, Santa Cruz, San Lorenzo Creek, San Ardo, Bradley, Casmalia, and Goleta areas in California; Sunnyside area, Utah; Muddy Creek and Jameson Ranch areas, Wyoming; Santa Rosa area, New Mexico; and the Cameron and Lawton Township areas, Oklahoma. Reserves of asphalt-bearing rocks in the se 13 areas range from a few thous and tons to about $2,800,000,000$ tons.

Those areas contai ning asphalts with a relatively large content of uranium, such as the Edna area, may be favorable areas in which to prospect for commercial-grade deposits of uranium in other types of rock. 
Table 2.--Summary of data from areas examined for uranium in asphalt-bearing rock

Map no.

(fig. 1)

California

$\begin{array}{cl}1 & \text { Point Arena } \\ 2 & \text { Santa Cruz } \\ 3 & \text { Chalone Creek } \\ 4 & \text { San Lorenzo Creek } \\ 5 & \text { San Ardo } \\ 6 & \text { Bradley } \\ 7 & \text { McKittrick }\end{array}$

\begin{aligned} 8 & Edna \\ 9 & Casmalia \\ 10 & Schumann \\ 11 & Los Alamos \\ 12 & Gaviota \\ 13 & Goleta \\ Utah & \\ \hline 14 & Whiterocks Canyon \\ 15 & Vernal \\ 16 & Bonanza \\ 17 & PR Springs \\ 18 & Sunnyside \\ Wyoming & \\ \hline 19 & Muddy Creek \\ 20 & Jameson Ranch \end{aligned}

Formation

sampled

Monterey sh.

Vaqueros ss.

Unnamed fm.

Unnamed fm.

Santa Margarita fm.

Unnamed fm.

Etchegoin $\mathrm{fm}$.

Tulare fm.,

Alluvium

Pismo fm.

Sisquoc fm.

Sisquoc fm.

Sisquoc $\mathrm{fm}$.

Monterey sh.

Monterey sh.

Navajo ss.

Uinta $\mathrm{fm}$.

Green River and

Uinta fms.

Green River fm.

Green River fm.

Fort Union fm.

Teapot ss. member of Mesaverde $\mathrm{fm}$.
Average Average Average

oil in ash in $U$ in

No. of samples oil ash samples (percent) (percent) (percent)

Age

Miocene

Mitocene

Pliocene

Pliocene

Miocene

Pliocene

Pliocene

Pliocene and.

Pleistocene

\section{Recent}

Pliocene

Pliocene

Pliocene

Pliocene

Miocene

Miocene

Jurassic

Eocene

Eocene

Eocene

Eocene

Paleocene

Cretaceous

$\begin{array}{ll}4 & 6.04 \\ 2 & 3.81\end{array}$

.59
.376

.040

.009

.081

.002

.023

.009

.028

.003

.014

.021

.040

.023 
Table 2. - Summary of data from areas examined for uranium in asphalt-bearing rocks.--Continued

Map no.

(fig. 1)

Area

$\frac{\text { Montana }}{21}$

Red Dome

New Mexico

\begin{tabular}{cl}
\hline Texas & Santa Rosa \\
\hline Oklahoma & Uvalde \\
\hline 24 & Parker \\
25 & Elgin \\
26 & Velma \\
27 & Baseline \\
28 & Woodford \\
29 & Dougherty \\
30 & Ada \\
31 & Fitzhugh \\
32 & Sulphur \\
33 & Bratcher \\
34 & Morgan \\
35 & Lone Grove \\
36 & Oil City \\
37 & Asphaltum \\
38 & Frisco Creek \\
39 & Cameron \\
40 & Lawton Township \\
Missouri & \\
\hline 41 & Deerfield \\
42 & Ellis \\
43 & Sheldon East \\
44 & Sheldon North \\
45 & Dry Wood Creek \\
&
\end{tabular}

Formation sampled

Chugwater fm.

Santa Rosa ss.

Anacacho 1s.

Wichita fm.

Wichita $\mathrm{fm}$.

Wichita $\mathrm{fm}$.

Wichita $\mathrm{fm}$.

Springer fm.

Viola 1s.

Ada $\mathrm{fm}$.

Ada $\mathrm{fm}$.

Oil Creek fm.

Deese $\mathrm{fm}$.

Deese $\mathrm{fm}$.

Wichita fm.

Wichita $\mathrm{fm}$.

Wichita $\mathrm{fm}$.

Wichita $\mathrm{fm}$.

Wichita $\mathrm{fm}$.

Wichita $\mathrm{fm}$.

Bartlesville sand

Bartlesville sand

Bartlesville sand

Bartlesville sand

Bartlesville sand

\section{Average}

oil in

No. of samples

Average

ash in

oi․

Average

samples (percent) (percent)

$U$ in

Age

4.91

0.60

0.010

Triassic

5

Triassic

6

3.99

1.24

.025

Cretaceous

11

8.52

.43

.002

Permian

Permian

Permian

Permian

2. 16

1.62

.004

1.76

1.98

.006

.94

1.68

.001

.98

2. 85

.005

2. 79

4. 95

.010

Ordovician

3. 18

.07

.001

Pennsylvanian 4

3.29

1. 95

.014

1.35

2. 00

.002

Ordovician

4.56

.70

.043

Pennsylvanian 3

Pennsylvanian 1

Permian

8.72

.59

.008

5.71

.76

.005

Permian

.87

3.31

.010

12.28

4.49

.002

Permian

6.15

1.60

.007

Permian

2. 08

10.39

.004

5.70

2. 06

.054

Permian

1. 19

3. 14

.020

Pennsylvanian 7

4.63

.79

.006

Pennsylvanian 3

4.64

.62

.145

Pennsylvanian 4

3.99

1.46

.016

Pennsylvanian 3

1. 43

1.27

.004

2. 30

1.58 


\section{ORIGIN OF T'HE URANIUM}

Little direct evidence on the origin of the uranium in asphalt is available. On the basis of field observations, however, it is believed that some of the uranium in the asphalt was present as an original constituent of the oil but that some uranium may have been introduced during the migration of the oil.

The concentration of uranium in the asphalts appears to bear no consistent relationship to the age of the host rock nor to the age of the original oil. Relatively high concentrations of uranium were found in one or more samples of asphalt-bearing rocks representing almost all the geologic ages examined, ranging from Ordovician to Pliocene. Comparison may best be made of the deposits in California and Oklahoma, the two states for which the most data are available. Most of the California deposits, which are Tertiary in age, are relatively high in uranium, whereas most of the Oklahoma deposits, which are Paleozoic in age, are relatively low in uranium, but this difference is believed due not so much to the relative age of the deposits as to the geologic environment during the origin or migration of the oil. 
Goldschmidt (1954, p. 495497 ) suggests that the marine environment of deposition of organic material, which is transformed into oil, is a reducing environment capable of precipitating various metals, including uranium, from the water. The hydrocarbons forming California asphalts originated in a marine environment which was probably rich in uranium and other metals derived from the abundant volcanic materials being deposited at the time of origin. All the Galifornia asphalts occur in formations of Miocene or later age and probably originated during the middle or late Miocene, a time of widespread and intense volcanic activity (Taliaferro in Jenkins, 1943, p. 142). The Miocene and younger formations contain large amounts of volcanic material, and granitic debris derived from the erosion of pre-Tertiary granite. The resulting rock types include arkosic conglomerate and sandstone, tuffaceous sandstone, diatomaceous sandstone and shale, and chert. Most of these rock types are relatively rich in uranium.

The hydrocarbonsfrom which most of the Oklahoma asphalts were formed originated during Ordovician or Pennsylvanian time in a marine environment which was probably low in uranium. Rock types associated with the Oklahoma asphalts include quartzose sandstones, limestones, conglomerates, and shales. Although some asphalt-bearing formations contain granitic material, it is in relatively small proportions. In general, the associated rock types are low in uranium and are not likely to have contributed above-average amounts of uranium to the marine waters in which the hydrocarbons now present as asphalt originated. 
The influence of associated rock types on the uranium content of asphalt is likewise significant if it is assumed that the uranium was acquired by the oil during its migration to the present reservoir rocks. The California rocks would provide a more abundant source of uranium than the Oklahoma rocks.

Another factor favoring a higher concentration of uranium in the California asphalts is that California crude oils are generally heavy oils and uranium tends to concentrate in the heavier, more asphaltic portions of petroleum (Erickson, Myers, and Horx, 1954, p. 2211).

\section{DESCRIPTION OF DEPOSITS}

\section{California}

The asphalt-bearing rocks in California appear to be generally more favorable for the occurrence of uranium than those examined in the other western states. In 11 of the 13 California areas sampled, the average uranium in the ash of the extracted oil ranged from 0.023 percent to 0.376 percent. Almost all the California asphalts examined occur in formations of Miocene or Pliocene age, and it is probable that the asphalt in most of these formations originated in bituminous marine shales of Miocene age, represented mainly by the Monterey shale and equivalent formations (H. W. Hoots in Jenkins, 1943, p. 270-275)。 
Point Arena area

Asphalt-bearing sandstone beds in the Monterey shale of Miocene age crop out on the sea coast just west of the town of Point Arena, Mendocino County. A sequence of interbedded shale, siltstone, and sandstone, 500 feet thick, contains 6 asphalt-bearing sandstone beds ranging in thickness from 1 to 30 feet. The beds crop out along parts of the east and south rim of a small northwestward plunging syncline and underlie an area of less than one-half square mile. Reserves of asphalt-bearing sandstone are estimated to be about 3,200, 000 tons (Holmes and others, 1951).

Samples collected in the Point Arena area

Sample Percent Percent Percent U

Location

no.

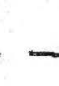

Just north of 97756

4.21 as

Arena Cove

97757

3.34

Coast Guard

97758

3.67

97759

5.52

97761

3.71

97762

6.08

0.52

0.039

.022

.027

.030

Remarks

Station

.64

.016

1.06

.044

Base of $15^{\circ}$ bed

Middle of $15^{\circ}$ bed

Top of $15^{\circ}$ bed

Base of $30^{\circ}$ bed

1.10

$16^{\prime}$ above base of $30^{\prime}$ bet $26^{\circ}$ above base of $30^{\prime}$ bed 
Santa Cruz area

Asphalt-bearing sandstone beds in the Vaqueros sandstone and Monterey shale of Miocene age crop out about 5 miles west of the city of Santa Cruz, Santa Cruz County. The two deposits in the area underlie about 3 square miles. The asphaltmbearing beds occur in a transition zone between the Vaqueros sandstone and the overlying Monterey shale. These formations vary greatly in thickness and lithology and lie unconformably on a siliceous quartz-diorite of pre-Cretaceous age. The asphalt-bearing beds are discontinuous and occur both as normally bedded sandstone and as sandstone dikes intruded into overlying shale beds. Total reserves of asphalt-bearing sandstone are estimated to be about 1,600,000 tons (Page and others, 1945b). There is no production at the present time.

Samples collected in the Santa Cruz area

Location \begin{tabular}{ccc}
$\begin{array}{c}\text { Sample } \\
\text { no. }\end{array}$ & $\begin{array}{c}\text { Percent } \\
\text { oil }\end{array}$ & $\begin{array}{c}\text { Percent Percent U } \\
\text { ash in oil in oil ash }\end{array}$ \\
\hline
\end{tabular}

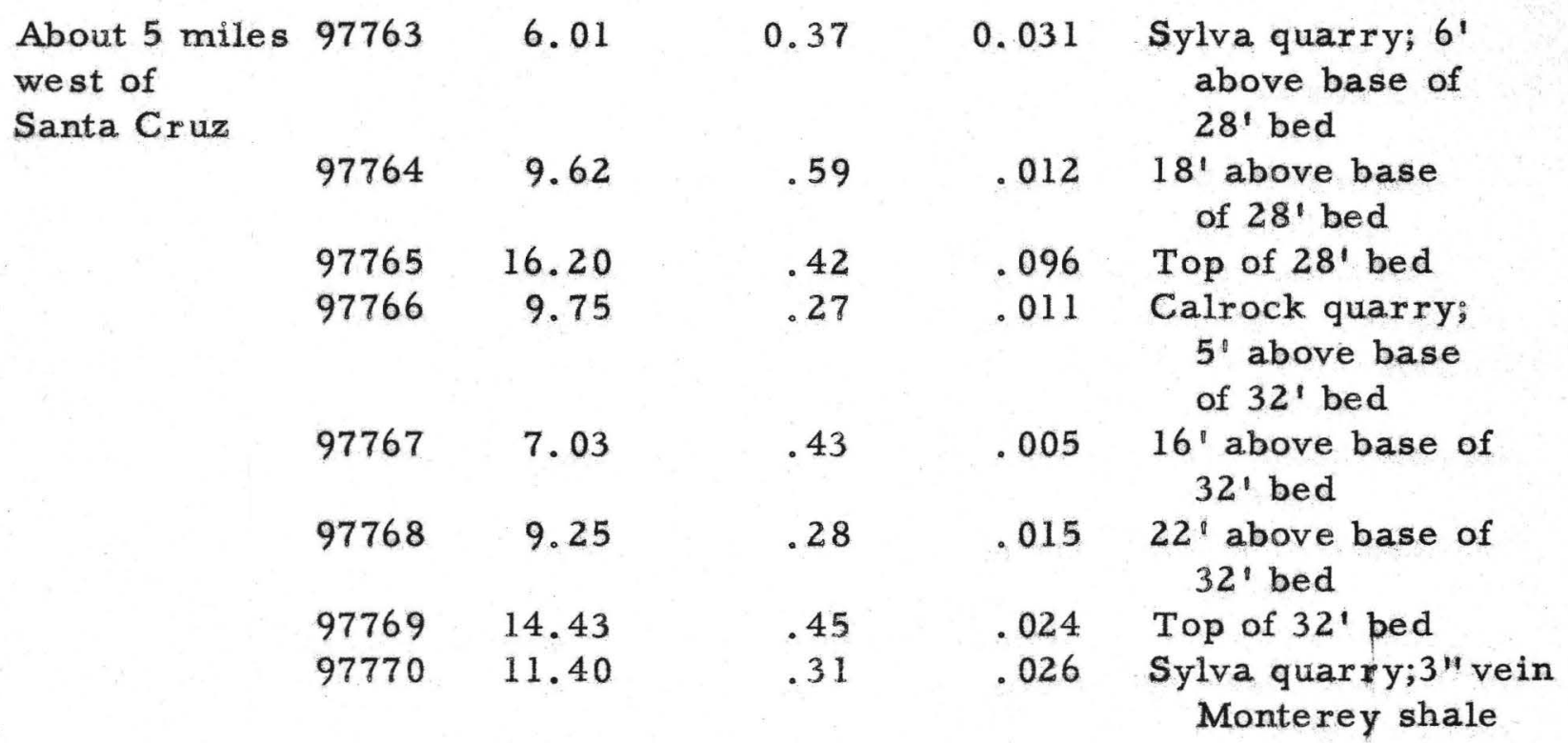


Chalone Creek and San. Lorenzo Creek areas

Asphalt-bearing arkose crops out along a small tributary of Chalone Creek, San Benito County, and along a small tributary of San Lorenzo Creek, Monterey County. The arkose in both areas is the basal part of a marine Pliocene formation which is in fault contact with pre-Cretaceous granite from which the arkose was derived (Bramlette and Daviess, 1944).

In the Chalone Creek area the asphalt-bearing arkose bed dips $40^{\circ}$ eastward and crops out for a distance of about a quarter of a mile along both sides of the creek valley. The bed is 37 feet thick on the west side of the valley and 21 feet thick in a small abandoned quarry on the east side of the valley.

In the San Lorenzo Creek area the asphalt-bearing arkose beds are as much as 30 feet thick and dip about $14^{\circ}$ to the southwest. Two abandoned quarries and several prospect pits mark the line of outcrop.

Samples collected in the Chalone Creek area

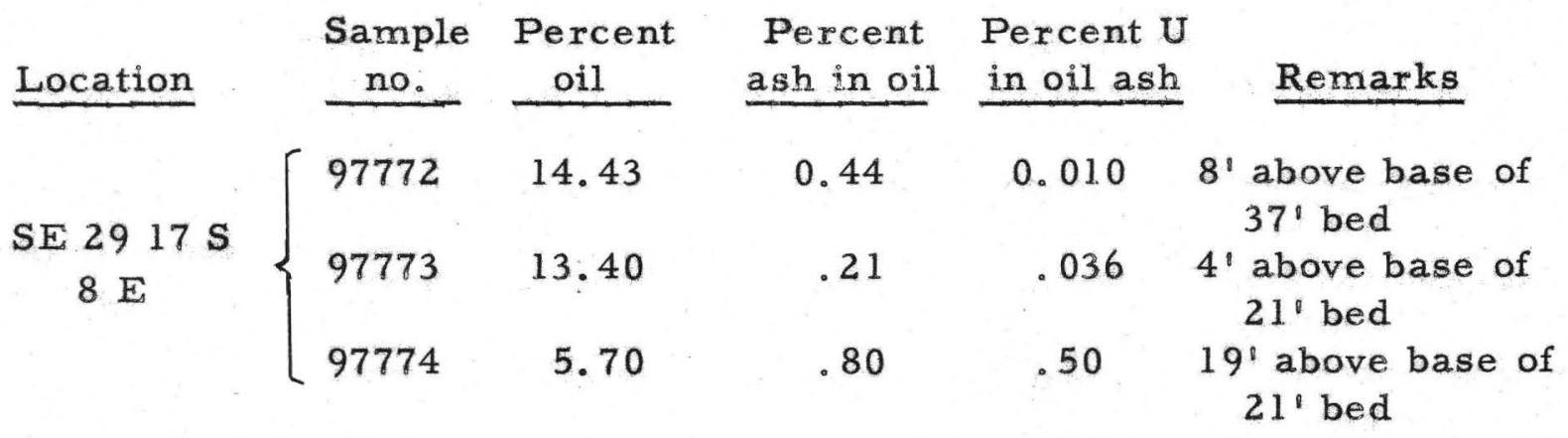

Samples collected in the San Lorenzo Creek area

\begin{tabular}{|c|c|c|c|c|c|}
\hline \multirow{3}{*}{$\begin{array}{l}\text { SE } 1519 \mathrm{~S} \\
9 \mathrm{E}\end{array}$} & 97746 & 8.57 & .15 & .043 & Middle of $13^{\prime}$ bed \\
\hline & 97747 & 14.41 & .26 & .037 & $25^{\circ}$ above base of \\
\hline & 97748 & & .28 & .017 & $\begin{array}{l}30^{\prime} \text { bed } \\
4^{\circ} \text { above base of } \\
30^{\circ} \text { bed. }\end{array}$ \\
\hline
\end{tabular}


San Ardo area

Asphalt-bearing sandstone crops out 2 to 3 miles west of the town of San Ardo, Monterey County. The asphalt-bearing beds may be as much as 125 feet thick and extend for 5 miles (Eldridge, 1901, p. 410). They occur in a transition zone between the Monterey shale and the Santa Margarita formation, both of Miocene age (Bramlette and Daviess, 1944). The beds dip to the east and crop out along the east flank of the hills bor dering the Salinas River. One locality was examined, where a thickness of 22 feet of asphalt-bearing sandstone, dipping $12^{\circ}$ to the east, is exposed in a gulley.

Samples collected in the San Ardo area

\begin{tabular}{|c|c|c|c|c|c|}
\hline Location & $\begin{array}{c}\text { Sample } \\
\text { no. }\end{array}$ & $\begin{array}{l}\text { Percent } \\
\text { oil } \\
\end{array}$ & $\begin{array}{r}\text { Percent } \\
\text { ash in oil }\end{array}$ & $\begin{array}{l}\text { Percent U } \\
\text { in oil ash }\end{array}$ & Remarks \\
\hline SE $1322 \mathrm{~S}$ & 97749 & 3.58 & 0.60 & 0.072 & $\begin{array}{l}16^{\prime} \text { above base of } \\
22^{\circ} \text { bed }\end{array}$ \\
\hline $9 \mathrm{E}_{s}$ & 97750 & 8.90 & .39 & .064 & $\begin{array}{l}4^{\prime} \text { above base of } \\
22^{\circ} \text { bed. }\end{array}$ \\
\hline
\end{tabular}

Bradley area

Asphalt occurs in the basal bed of marine Pliocene rocks, which unconformably overlie the Monterey shale, about 6 miles southwest of Bradley, Monterey County (Eldridge, 1901, p. 411-12; Bramlette and Daviess, 1944). The asphalt-bearing bed crops out on both sides of the San Antonio River and dips about $12^{\circ}$ to the northeast. It is mainly a fine-to medium-grained sandstone, but some layers are conglomeratic. The outcrop is poorly exposed but the asphalt-bearing bed appears to be about 15 to 20 feet thick. 
Samples collected in the Bradley area

\section{Location}

SW $3524 \mathrm{~S}$

$10 \mathrm{E}$
Sample Percent Percent Percent U

no. oil ashin oil in oil ash Remarks

$97751 \quad 10.49 \quad 0.437 \quad 0.045$

\section{McKittrick area}

Large deposits of asphalt in the form of asphalt-bearing sandstone, asphalt-bearing alluvium, oil seeps, and vein asphalt, crop out near the town of McKittrick, Kern County. The deposits occur in various rock types in the Monterey shale of Miocene age, the Etchegoin formation of Pliocene age, the Tulare formation of Pliocene and early Pleistocene age, and recent alluvium. The rocks in the area are highly folded and faulted, and the asphalt deposits, as well as a small producing oil field, are associated with these structures. The total reserves in the area are about 15,700, 000 tons of asphalt-bearing rock (Page and others, 1945a).

Samples collected in the McKittrick area

Location

SW $2830 \mathrm{~s}$

$22 \mathrm{E}$

$\mathrm{NE} 29.30 \mathrm{~S}$

$22 \mathrm{E}$
Sample Percent Percent Percent U

no. oil ash in oil in oil ash Remarks

\begin{tabular}{|c|c|c|c|c|}
\hline 97752 & 5.27 & 3.32 & 0.060 & $\begin{array}{l}\text { Middle of } 6^{\prime} \text { bed of } \\
\text { asphalt-bearing } \\
\text { sandstone }\end{array}$ \\
\hline 97753 & 79.50 & .51 & .019 & $\begin{array}{l}\text { As phalt vein } 2-1 / 2^{\prime} \\
\text { thick }\end{array}$ \\
\hline 97754 & 39.00 & 1.54 & .006 & $\begin{array}{l}\text { Asphalt seep in } \\
\text { alluvium }\end{array}$ \\
\hline 97755 & 5.65 & 2.85 & .002 & $\begin{array}{l}\text { Asphalt seep in } \\
\text { alluvium }\end{array}$ \\
\hline 255611 & 5.13 & .19 & .150 & $\begin{array}{l}\text { Asphalt-bearing } \\
\text { sandstone (Sample } \\
\text { was submitted by } \\
\text { P. D. Snavely) }\end{array}$ \\
\hline
\end{tabular}


Edna area

The deposits of asphalt-bearing sandstone in the Edna area, San. Luis Obispo County, contain the highest concentration of uranium of all the deposits examined in the western states. The uranium content of seven samples collected in the Edna area ranges from 0.035 to 1.9 percent and averages 0.376 percent in the ash of the extracted oIl. The 10cation of sample localities and the extent of the asphalt-bearing rocks are shown on the geologic map of part of the Edna area (fig. 2).

The asphalt occurs in the Pismo formation of late Miocene and Pliocene age, which unconformably overlies the Monterey shale of Miocene age. The Monterey shale in the Edna area consists of tuff, diatomaceous and siliceous shale, and chert. The Pismo formation consists of varied rock types including conglomerate, arkosic sandstone, diatomaceous sandstone, sandy and silty shale, diatomaceous shale, siliceous shale, and chert. The asphalt is irregularly distributed in lenticular and discontinuous beds of arkosic sandstone which range in thickness from a few feet to almost 300 feet. The irregular distribution appears to be related to the variation in the permeability of the sandstones.

The largest deposits of asphalt -bearing sandstone crop out on the nor theast flank of a northwest-trending syncline near Pismo Creek. The total reserves of asphalt-bearing sandstone are about $280,000,000$ tons (Page and others, 1944). There is no production of asphalt-bearing sandstone at the present time. 


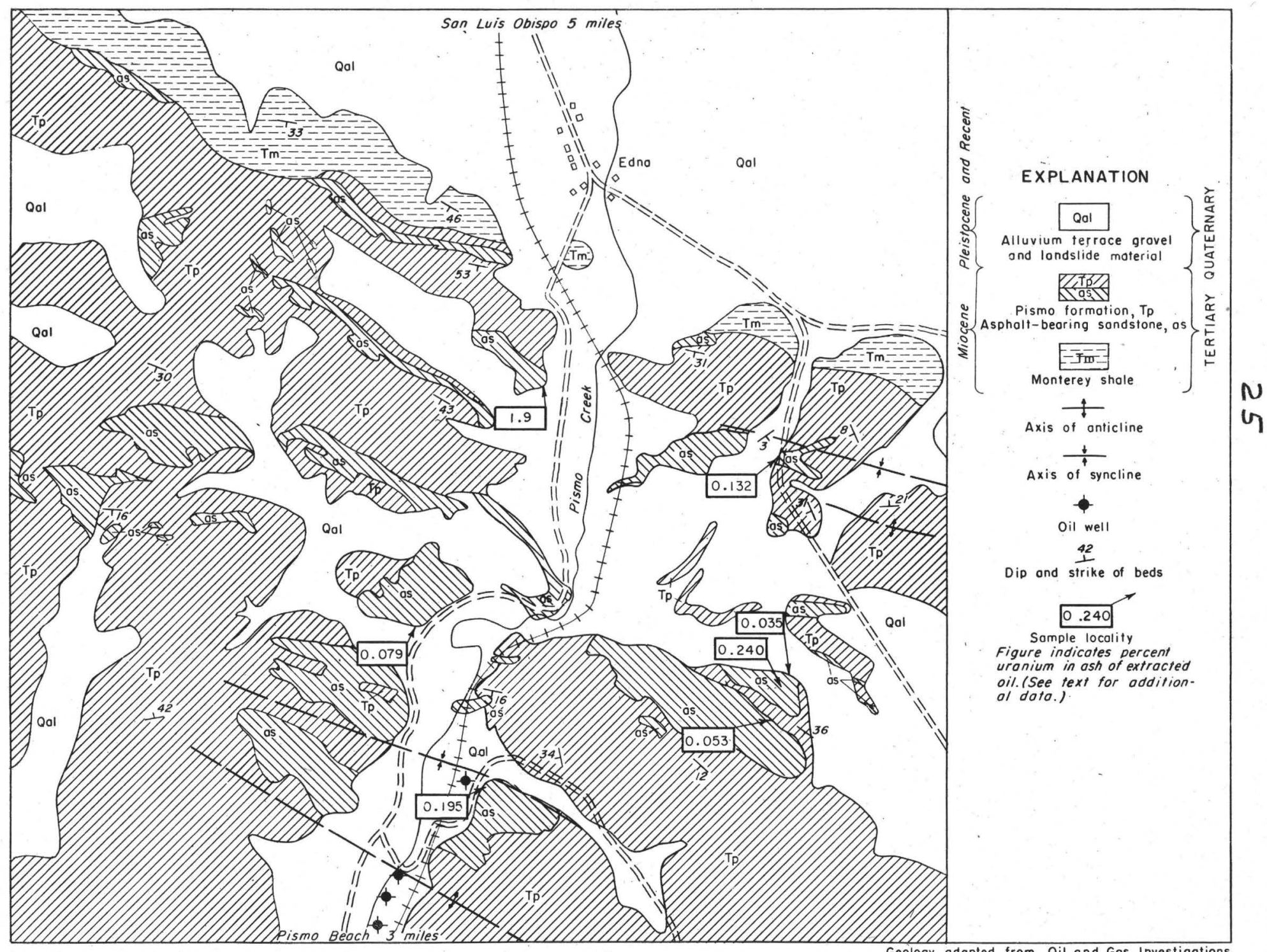

Geology odopted from Oil and Gas Investigation

FIGURE2.-GEOLOGIC MAP OF PART OF THE EDNA AREA, SAN LUIS OBISPO COUNTY, CALIFORNIA $2000,1000,9 \quad 20,000$ 4 4000 feet 
Samples collected in the Edna area

Location

See fig. 2 for locations

\begin{tabular}{|c|c|c|c|c|}
\hline $\begin{array}{c}\text { Sample } \\
\text { no. }\end{array}$ & $\begin{array}{l}\text { Percent } \\
\quad \text { oil }\end{array}$ & $\begin{array}{l}\text { Percent } \\
\text { ash in oil }\end{array}$ & $\begin{array}{l}\text { Percent U } \\
\text { in oil ash }\end{array}$ & Remarks \\
\hline 99133 & 3.16 & 1.00 & 0.195 & $\begin{array}{l}\text { Lower part of bed } \\
\text { more than } 100^{\circ} \\
\text { thick }\end{array}$ \\
\hline 99134 & 4.86 & .76 & .079 & $\begin{array}{l}\text { Upper part of bed } \\
\text { more than } 300^{\circ} \\
\text { thick }\end{array}$ \\
\hline 99135 & 7.60 & .37 & 1.9 & $\begin{array}{l}\text { Thickness of bed } \\
\text { not known; prob- } \\
\text { ably between } 50^{\prime} \\
\text { and } 100^{\circ}\end{array}$ \\
\hline 99136 & 10.15 & .14 & .132 & $\begin{array}{l}\text { Upper part of bed } \\
\text { about } 50^{\circ} \text { thick }\end{array}$ \\
\hline 99137 & 6.48 & .70 & .053 & Base of $120^{\prime}$ bed \\
\hline 99138 & 4.80 & .51 & .240 & $\begin{array}{l}\text { Upper part of } 230^{\circ} \\
\text { bed }\end{array}$ \\
\hline 99139 & 7.01 & .46 & .035 & $\begin{array}{l}\text { Lower part of } 230^{\circ} \\
\text { bed }\end{array}$ \\
\hline
\end{tabular}

Casmalia area

A deposit of asphalt-bearing diatomaceous mudstone is exposed about 4 miles north of the village of Casmalia, Santa Barbara County, at the N.T.U. open pit mine, now abandoned. Similar beds crop out half a mile northeast of the N. T. U. mine and in the Schumann area, 3 miles to the southeast; the asphalt-bearing beds may be continuous through the se areas. 
The asphalt impregnates nor theastward-dipping beds of diatomaceous mudstone in the upper part of the Sisquoc formation, which in this area is Miocene and Pliocene in age. The asphalt-bearing beds may be as much as 20 feet thick at the N.T.U. mine, but the extent of down-dip impregnation is not known. Estimated reserves at the N.T.U. mine are only about 100,000 tons of asphalt-bearing rock (Williams and Holmes, 1945), but reserves for the entire area are undoubtedly much greater.

\section{Samples collected in the Casmalia area}

\begin{tabular}{|c|c|c|c|c|c|}
\hline Location & $\begin{array}{c}\text { Sample } \\
\text { no. }\end{array}$ & $\begin{array}{c}\begin{array}{c}\text { Percent } \\
\text { oil }\end{array} \\
\end{array}$ & $\begin{array}{r}\text { Percent } \\
\text { ash in oil } \\
\end{array}$ & $\begin{array}{l}\text { Percent } \\
\text { in oil ash }\end{array}$ & Remarks \\
\hline & {$[99140$} & 27.80 & 0.18 & 0.041 & Base of $20^{\prime}$ bed \\
\hline N. T. U. mine & 99151 & 29.20 & .22 & .033 & Middle of $20^{\circ}$ bed \\
\hline $39 \mathrm{~N} 35 \mathrm{~W}$ & 99152 & 31.70 & .18 & .047 & $\begin{array}{l}\text { Upper part of } 20^{\circ} \\
\text { bed }\end{array}$ \\
\hline
\end{tabular}

\section{Los Alamos area}

Thick beds of asphalt-bearing sandstone crop out along the front of the San Rafael Mountains in the vicinity of Asphaltum and LaZaca Creeks, about 9 miles northeast of the town of Los Alamos, Santa Barbara County (Eldridge, 1901, p. 429-39). The asphalt-bearing sandstone beds are in the Sisquoc formation which in this area is Pliocene in age. An angular unc onformity separates the Sisquoc formation from the underlying Monterey shale of Miocene age, which is composed mainly of porcelaneous diatomite and siliceous shale. The Sisquoc formation in this area is composed mainly of medium - to fine-grained sandstone with thin beds of conglomerate containing pebble of chert and silicified shale similar to that in the underlying Monterey shale. 
In the cliffs southeast of Asphaltum Creek, the exposed asphaltbearing beds have an aggregate thickness of about 225 feet, and the intervening barren zones, an aggregate thickness of about 35 feet. The asphalt-bearing beds extend for a distance of about 5 miles along their outcrop and probably underlie an area of at least 5 square miles.

Samples collected in the Los Alamos area

\begin{tabular}{|c|c|c|c|c|c|}
\hline Location & $\begin{array}{c}\text { Sample } \\
\text { no. }\end{array}$ & $\begin{array}{c}\text { Percent } \\
\text { oil } \\
\end{array}$ & $\begin{array}{l}\text { Percent } \\
\text { ash in oil }\end{array}$ & $\begin{array}{l}\text { Percent U } \\
\text { in oil ash }\end{array}$ & Remarks \\
\hline $\begin{array}{l}2 \text { miles NE } \\
\text { of junction }\end{array}$ & 99148 & 3.20 & 1.75 & 0.038 & $\begin{array}{l}\text { Thickness of bed } \\
\text { not known }\end{array}$ \\
\hline $\begin{array}{l}\text { of Foxen } \\
\text { Canyon and }\end{array}$ & 99149 & 10.81 & .83 & .330 & $\begin{array}{l}8^{\prime} \text { above base of } \\
93^{\circ} \text { bed }\end{array}$ \\
\hline $\begin{array}{l}\text { Alisas } \\
\text { Canyon }\end{array}$ & 99150 & 14.60 & .57 & .073 & $\begin{array}{c}63^{\prime} \text { above base of } \\
93^{\prime} \text { bed }\end{array}$ \\
\hline roads & $\begin{array}{l}99151 \\
99152\end{array}$ & $\begin{array}{l}15.70 \\
16.10\end{array}$ & $\begin{array}{l}.28 \\
.68\end{array}$ & $\begin{array}{l}.059 \\
.010\end{array}$ & $\begin{array}{l}\text { Middle of } 33^{\prime} \text { bed } \\
95^{\prime} \text { above base of }\end{array}$ \\
\hline & 99153 & 17.50 & .05 & .036 & $\begin{array}{l}42^{\circ} \text { above base of } \\
99^{\circ} \text { bed }\end{array}$ \\
\hline & 99154 & 8.90 & 1.34 & .023 & $\begin{array}{l}5^{\circ} \text { above base of } \\
99^{\circ} \mathrm{bed}\end{array}$ \\
\hline
\end{tabular}

Other areas

Deposits of asphalt-bearing rocks were also examined in the Schumann, Gaviota, and Goleta areas, Santa Barbara County. In the Schumann area, about 2 miles north of the village of Casmalia, asphalt occurs throughout a section of diatomaceous mudstone reported to be as much as 340 feet thick. These beds are in the Sisquoc formation of Miocene and Pliocene age, and the occurrence is similar to that in the Casmalia area, 3 miles to the northwest. 
A bed of weathered asphalt-bearing sandstone in the Monterey shale of Miocene age is exposed on the seacoast at the mouth of Gaviota Canyon, Santa Barbara County. The asphalt-bearing bed is about 12 feet thick and is enclosed between beds of shale which contain small amounts of asphalt along bedding planes and joints.

Asphalt-bearing siltstone in the Monterey shale of Miocene age crops out along the seacoast at Goleta Beach County Park, about 5 miles west of the city of Santa Barbara, Santa Barbara County. Several beds of lenticular asphalt-bearing siltstone, the thickest of which is 20 feet, occur within a section about 100 feet thick.

\section{Sample collected in the Schumann area}

\section{Sample Percent Percent Percent U}

Location

no. oil
ash in oil in oil ash Remarks

Airox Quarry, $99146 \quad 17.88 \quad 0.23 \quad 0.009 \quad 158^{\prime}$ above base of 2 miles north $200^{\prime}$ bed of Casmalia

Sample collected in the Gaviota area

$\begin{array}{lllll}\text { Mouth of } & 99156 \quad 23.32 & 1.04 & .002 & \text { Seep in shale joints }\end{array}$ Gaviota

Canyon

Samples collected in the Goleta area $204 \mathrm{~N} 28 \mathrm{~W}\left\{\begin{array}{lllll}99157 & 16.18 & 2.00 & .023 & \text { Middle of } 20^{\circ} \mathrm{bed} \\ 99158 & 21.70 & 2.11 & .024 & \text { Top of } 15^{\prime} \mathrm{bed}\end{array}\right.$ 


\section{Utah}

All five of the asphalt-bearing areas sampled in the Utah area are in the Uinta Basin in the east-central part of the State. The deposits in the Vernal, Bonanza, PR Springs, and Sunnyside areas are in the Uinta and Green River formations of Eocene age, and the deposit in the WhiteRocks Canyon area is in the Navajo sandstone of Jurassic(?) age. The asphalt deposits in the Bonanza area are gilsonites, and the deposits in the other areas are asphalt-bearing sandstones.

\section{Vernal area}

The asphalt in the Vernal area, Uintah County, was the most uraniferous examined in Utah. The uranium content of 21 samples ranges from less than 0.001 to 0.150 percent and averages 0.028 percent in the ash of the extracted oil.

The deposits occur mainly in the Uinta formation of Eocene age, exposed along Asphalt Ridge just west of the town of Vernal. The asphalt impregnates lenticular sandstone beds ranging in thickness from a few feet to 190 feet, within a section which may be as much as 300 feet thick. Most of the asphalt-bearing beds are in the basal part of the Uinta formation, but some of the lowest beds may be in the upper part of the Mesaverde formation of Cretaceous age. The Uinta formation lies unconformably on the Mesaverde in this area. The Uinta formation in this area consists of red and cream colored shale and sandstone, and coarse siliceous conglomerate. The upper part of the Mesaverde formation in this area 
consists mainly of medium-grained buff sandstone. Where they contain asphalt, the sandst ones of the two formations are indisting uishable. Estimated reserves of asphalt-bearing sandstone in the area are $1,970,000,000$ tons (Spieker, 1930, p. 96-97). One quarry was operating in 1953, and the product was used locally for road construction.

The Vernal deposits were sampled in 1951 by Vine and Moore (1952) and in 1952 by Vine and Flege (1953), who took 13 samples from 9 localities along most of the 14-mile length of Asphalt Ridge. Nine additional samples were collected in 1953 for the present investigation.

Samples collected in the Vernal area

\begin{tabular}{|c|c|c|c|c|c|}
\hline Location & $\begin{array}{c}\text { Sample } \\
\text { no. }\end{array}$ & $\begin{array}{c}\text { Percent } \\
\text { oil } \\
\end{array}$ & $\begin{array}{l}\text { Percent } \\
\text { ash in oi }\end{array}$ & $\begin{array}{l}\text { Percent U } \\
\text { in oil ash }\end{array}$ & Remarks \\
\hline & 85728 & 16.0 & 1.77 & 0.002 & Samples 85728 \\
\hline \multirow{2}{*}{$254 \mathrm{~S} 20 \mathrm{E}$} & 85729 & 11.4 & 5.90 & .001 & through 85739 \\
\hline & 85730 & 3.1 & .96 & .021 & were collected \\
\hline \multirow{2}{*}{$114 \mathrm{~S} 20 \mathrm{E}$} & $\{85731$ & 12.3 & 6.31 & .001 & by J. D. Vine \\
\hline & $\lfloor 85732$ & 13.0 & 3.82 & .005 & and others in \\
\hline $304 \mathrm{~S} 21 \mathrm{E}$ & 85733 & 10.8 & 3.68 & .007 & 1951 and 1952 , \\
\hline \multirow{2}{*}{$314 \mathrm{~S} 21 \mathrm{E}$} & 85734 & 11.6 & 8.42 & .001 & and reported in \\
\hline & 85735 & 6.6 & 1.35 & .026 & TEI-336. \\
\hline $45 \mathrm{~S} 21 \mathrm{E}$ & 85736 & 10.0 & 2.66 & .001 & \\
\hline $95 \mathrm{~S} 21 \mathrm{E}$ & 85737 & 7.4 & 3.45 & .005 & \\
\hline $235 \mathrm{~S} 21 \mathrm{E}$ & 85738 & 8.0 & 2.75 & .017 & \\
\hline \multirow[t]{3}{*}{$255 \mathrm{~S} 21 \mathrm{E}$} & 85739 & 9.4 & 3.24 & .002 & \\
\hline & {$[96056$} & 1.35 & 2.46 & .013 & Lower part of $12^{\prime}$ bed \\
\hline & 96057 & 1.85 & 2.04 & .034 & Upper part of $55^{\prime}$ bed \\
\hline \multirow[t]{3}{*}{$294 \mathrm{~S} 21 \mathrm{E}$} & 96058 & 5.50 & 2.21 & .005 & Lower part of $55^{\circ} \mathrm{bed}$ \\
\hline & 96059 & 2.09 & .49 & .177 & Upper part of $66^{\prime}$ bed \\
\hline & {$[96061$} & .98 & .83 & .008 & Upper part of $26^{\prime}$ bed \\
\hline \multirow[t]{3}{*}{$324 \mathrm{~S} 21 \mathrm{E}$} & 96062 & 7.04 & 1.50 & .015 & Middle of $19^{\prime}$ bed \\
\hline & 96063 & 4.76 & .93 & .150 & Lower part of $38^{\prime}$ bed \\
\hline & (96064 & 8.63 & 1.13 & .141 & Lower part of $7^{\circ}$ bed \\
\hline $204 \mathrm{~S} 21 \mathrm{E}$ & 96065 & 10,10 & .53 & .010 & Mill pile \\
\hline
\end{tabular}




\section{Sunnyside area}

The largest known asphalt-bearing sandstone deposits in the United States are those near Sunnyside, Carbon County (Holmes, Page, and Averitt, 1948). The total measured, indicated, and inferred reserves in beds more than 10 feet thick axe about $2,800,000,000$ tons of asphaltbearing sandstone. The asphalt occurs in lenticular sandstone beds ranging in thickness from a few inches to 350 feet, whithin a stratigraphic interval of about 1,000 feet in the uppex part of the Wasatch and lower part of the Green River formations of Eocene age. The beds dip northward and crop out for a distance of about 9 miles along the steep scarp of the Book Cliffs which form the south rim of the Uinta Basin. There has been no production of asphalt-bearing sandstone from the Sunnyside area since about 1948, but quarrying and prospecting have been extensive in the past. The material was used for road paving.

Samples collected in the Sunnyside area

\begin{tabular}{|c|c|c|c|c|c|}
\hline Location & $\begin{array}{c}\text { Sample } \\
\text { no. } \\
\end{array}$ & $\begin{array}{c}\text { Percent } \\
\text { oil } \\
\end{array}$ & $\begin{array}{l}\text { Percent } \\
\text { ash in oil }\end{array}$ & $\begin{array}{l}\text { Percent U } \\
\text { in oil ash }\end{array}$ & Remarks \\
\hline & C94103 & 1.80 & 1.17 & 0.046 & Upper part of $45^{\prime}$ bed \\
\hline $\mathrm{NE} 1514 \mathrm{~S}$ & 94102 & 6.17 & .90 & .041 & Lower part of $28^{\prime}$ bed \\
\hline \multirow[t]{3}{*}{$14 \mathrm{E}$} & 94101 & 6.93 & 1.59 & .012 & Middle of $50^{\circ}$ bed \\
\hline & 94100 & 10.65 & .75 & .020 & Lower part of $18^{\prime}$ bed \\
\hline & {$[94106$} & 5.46 & 3.68 & .010 & Middle of $25^{\circ}$ bed \\
\hline NW $1014 \mathrm{~S}$ & 94105 & 1.56 & .83 & .014 & Middle of $60^{\prime}$ bed \\
\hline \multirow[t]{2}{*}{$14 \mathrm{E}$} & 94104 & 3.10 & 1.27 & .005 & Middle of $30^{\prime}$ bed \\
\hline & {$[94108$} & 6.05 & .45 & .003 & $17^{\prime}$ below top of $82^{\prime}$ bed \\
\hline \multirow[t]{3}{*}{414 S $14 \mathrm{E}$} & 200931 & 5.88 & .30 & .048 & $33^{\circ}$ below top of $82^{\prime}$ bed \\
\hline & 94109 & 9.60 & .30 & .015 & $77^{\circ}$ below top of $82^{\circ}$ bed \\
\hline & 94107 & 1.97 & .87 & .015 & Lower part of $22^{\circ}$ bed \\
\hline
\end{tabular}




\section{Other areas}

Deposits of asphalt-bearing sandstones were also examined in the PR Springs area, Grand and Uintah Counties, and the Whiterocks Canyon area, Uintah County; deposits of gilsonite were examined in the Bonanza area, Uintah County. Samples collected from these areas were generally low in uranium.

The asphalt of the PR Springs area is in sandstone beds in the lower part of the Green River formation of Eocene age (W. B. Cashion, personal communication), and the occurrence is similar to that in the Sunnyside area. The asphalt of the Whiterocks Canyon area impregnates sandstone beds of the Navajo sandstone of Jurassic(?) age, which in this area aggregates about 936 feet in thickness (Kinney and Rominger, 1947). The, gilsonites of the Bonanza area occur in veins chiefly in the Green River, Uinta, and Wasatch formations of Eocene age (Cashion and Brown, in press).

Samples collected in the PR Springs area

\begin{tabular}{|c|c|c|c|c|c|}
\hline Location & $\begin{array}{c}\text { Sample } \\
\text { no. }\end{array}$ & $\begin{array}{c}\text { Percent } \\
\text { oil } \\
\end{array}$ & $\begin{array}{r}\text { Percent } \\
\text { ash in oil }\end{array}$ & $\begin{array}{l}\text { Percent U } \\
\text { in oil ash }\end{array}$ & Remarks \\
\hline & 96044 & 12.0 & 0.24 & 0.011 & Base of $22^{\circ}$ bed \\
\hline $5151 / 2 \mathrm{~s}$ & 96045 & 9.50 & .55 & .063 & $5^{\circ}$ above base of $22^{\prime}$ bed \\
\hline \multirow[t]{4}{*}{$23 \mathrm{E}$} & 96046 & 7.13 & .37 & .025 & $10^{\circ} \mathrm{above}$ base of $22^{\circ} \mathrm{bed}$ \\
\hline & 96047 & 9.86 & 3.05 & .005 & $15^{\circ}$ above base of $22^{\circ} \mathrm{bed}$ \\
\hline & 96048 & 4.99 & 1.40 & .009 & $20^{\prime}$ above base of $22^{\prime} \mathrm{bed}$ \\
\hline & 96050 & 4.22 & .73 & .006 & $9^{\prime}$ above base of $52^{\prime}$ bed \\
\hline $3615 \mathrm{~S}$ & 96051 & 4.45 & 1.08 & .003 & $18^{\circ}$ above base of $52^{\circ} \mathrm{bed}$ \\
\hline \multirow[t]{3}{*}{$23 \mathrm{E}$} & 96053 & 4.76 & 1.46 & .009 & $36^{\circ} \mathrm{above}$ base of $52^{\circ} \mathrm{bed}$ \\
\hline & 96054 & 3.82 & .76 & .004 & $45^{\circ}$ above base of $52^{\prime} \mathrm{bed}$ \\
\hline & 96055 & 4.89 & 1.46 & .009 & Top of $52^{\circ}$ bed \\
\hline
\end{tabular}


Samples collected in the Whiterocks Canyon area

\begin{tabular}{|c|c|c|c|c|c|}
\hline Location & $\begin{array}{c}\text { Sample } \\
\text { no. }\end{array}$ & $\begin{array}{c}\text { Percent } \\
\text { oil } \\
\end{array}$ & $\begin{array}{r}\text { Percent } \\
\text { ash in oil } \\
\end{array}$ & $\begin{array}{l}\text { Percent } 0 \\
\text { in oil ash }\end{array}$ & Remarks \\
\hline $182 \mathrm{~N} 1 \mathrm{E}$ & 94110 & 5.60 & 0.72 & 0.024 & $\begin{array}{l}\text { Lower part of } 936^{\circ} \\
\text { section }\end{array}$ \\
\hline & 94111 & 9.72 & .24 & .003 & $\begin{array}{c}300^{\prime} \text { above base of } \\
936^{\circ} \text { section }\end{array}$ \\
\hline $192 \mathrm{~N} 1 \mathrm{E}$ & $\begin{array}{l}94112 \\
94113\end{array}$ & $\begin{array}{r}2.93 \\
4.13\end{array}$ & $\begin{array}{r}1.00 \\
.68\end{array}$ & $\begin{array}{r}.005 \\
.003\end{array}$ & $\begin{array}{c}600^{\prime} \text { above base of } \\
936^{\circ} \text { section } \\
800^{\circ} \text { above base of } \\
936^{\circ} \text { section }\end{array}$ \\
\hline
\end{tabular}

Samples collected in the Bonanza area

\begin{tabular}{|c|c|c|c|c|c|}
\hline $79 \mathrm{~S} 25 \mathrm{E}$ & 96037 & $(100)$ & .31 & .003 & Gils onite, Cowboy Vein \\
\hline $169 \mathrm{~S} 25 \mathrm{E}$ & 96038 & $(100)$ & 1.02 & .004 & Gilsonite, Cowboy Vein \\
\hline $309 \mathrm{~S} 25 \mathrm{E}$ & 96039 & $(100)$ & .45 & .004 & Gilsonite, Tabor Vein \\
\hline $259 \mathrm{~S} 24 \mathrm{E}$ & 96040 & $(100)$ & .49 & .002 & $\begin{array}{l}\text { Gilsonite, Independent } \\
\text { Vein }\end{array}$ \\
\hline $259 \mathrm{~S} 24 \mathrm{E}$ & 96041 & $(100)$ & .56 & .001 & Gilsonite, Chapetta Vein \\
\hline $359 \mathrm{~S} 24 \mathrm{E}$ & 96042 & $(100)$ & .31 & .005 & $\begin{array}{l}\text { Gilsonite, Wagonhound } \\
\text { Ve in }\end{array}$ \\
\hline $2411 \mathrm{~S} 24 \mathrm{E}$ & 96043 & $(100)$ & .23 & .003 & Gilsonite, Rainbow Vein \\
\hline
\end{tabular}

Lenticular beds of highly weathered asphalt-bearing sandstone in the Fort Union formation of Paleocene age crop out near Muddy Creek about 17 miles south of Creston, Carbon County (Jamison, 1912, p. 47). In this area the Fort Union formation dips southwest about $4^{\circ}$. The asphalt occurs throughout a section of sandstone about 100 feet thick, but the richest impregnation is in the lower 15 feet and in a 5-foot zone in the upper part of the section. The outcrop of asphalt-bearing sandstone extends about 2 miles along Wyoming highway 330 in secs. 3,10 , and 15 , T. 17 N., R. $92 \mathrm{~W}$. The most complete exposures are in several outliers 
forming low hills a few hundred feet east of the bighway. The westward underground extent of the asphalt -bearing beds is not known.

Samples collected in the Muddy Creek area

Sample Percent Percent Percent u

Location no. oil ash in oil in oil ash Renraxks

\begin{tabular}{|c|c|c|c|c|c|}
\hline $\mathrm{NE} 1517 \mathrm{~N} 9$ & $\sqrt{213818}$ & 6.35 & 0.29 & 0.091 & Lower part of $15^{\prime}$ bed \\
\hline NF & $\sqrt{2} 13819$ & 5.70 & .42 & .032 & Upper part of $30^{\circ}$ bed \\
\hline 25 & 213820 & 6.00 & .34 & .021 & Middle of $5^{\circ}$ bed \\
\hline N $317 \mathrm{~N} 92 \mathrm{~W}$ & 213821 & 6.11 & .38 & .015 & Top of $15^{\circ}$ bed \\
\hline
\end{tabular}

Jameson Ranch area

The Teapot sandstone member of the Mesaverde formation of Cretaceous age is saturated with asphalt along its outcrop in secs. 4, 5, and 9 , T. 33 N., R. 87 W., Natrona County (Hares, 1917, p. 247). The asphaltbearing sandstone forms a prominent hogback which dips about $24^{\circ}$ to the nor the ast off the east flank of the Rattle snake Range. The outcrop extends about a quarter of a mile, and the maxirnum exposed thickness of the asphalt-bearing beds is about 50 feet. The asphalt is highly weathered and is now represented only by brown staining throughout the exposed beds. No similar exposures of asphalt beaxing Teapot sandstone have been reported in this area.

Samples collected in the Jameson Ranch area

\begin{tabular}{|c|c|c|c|c|c|}
\hline Location & $\begin{array}{c}\text { Sample } \\
\text { no. }\end{array}$ & $\begin{array}{l}\text { Percent } \\
\text { oil } \\
\end{array}$ & $\begin{array}{c}\text { Percent } \\
\text { ash in oil }\end{array}$ & $\begin{array}{l}\text { Percent } \\
\text { in oil ash }\end{array}$ & Remarks \\
\hline \multirow{2}{*}{$533 \mathrm{~N} 87 \mathrm{~W}$} & & 4.00 & 0.84 & & $\begin{array}{c}27^{\circ} \text { above base of } \\
47^{\circ} \text { bed }\end{array}$ \\
\hline & 213828 & 3.62 & .34 & .032 & $\begin{array}{l}7^{7} \text { above base of } \\
47^{\circ} \text { bed }\end{array}$ \\
\hline
\end{tabular}




\section{Montana}

Red Dome area

Asphalt-bearing sandstone in the Chugwater formation of Triassic age crops out along the rim of the breached top of Red Dome, Carbon County (Knappen and Moulton, 1930, p. 58). The asphalt contains relatively small amounts of uranium. The Chugwater formation is exposed in an irregular area of about $1-1 / 2$ square miles at the crest of Red Dome. The asphalt impregnates the top 20-27 feet of the uppermost sandstone of the Chugwater immediately below clays of the Sundance formation of Jurassic age. There are no other exposures of the asphaltbearing sandstone in the area other than those along the steep inner rim of the dome, and the underground extent of the beds is unknown.

Samples collected in the Red Dome area

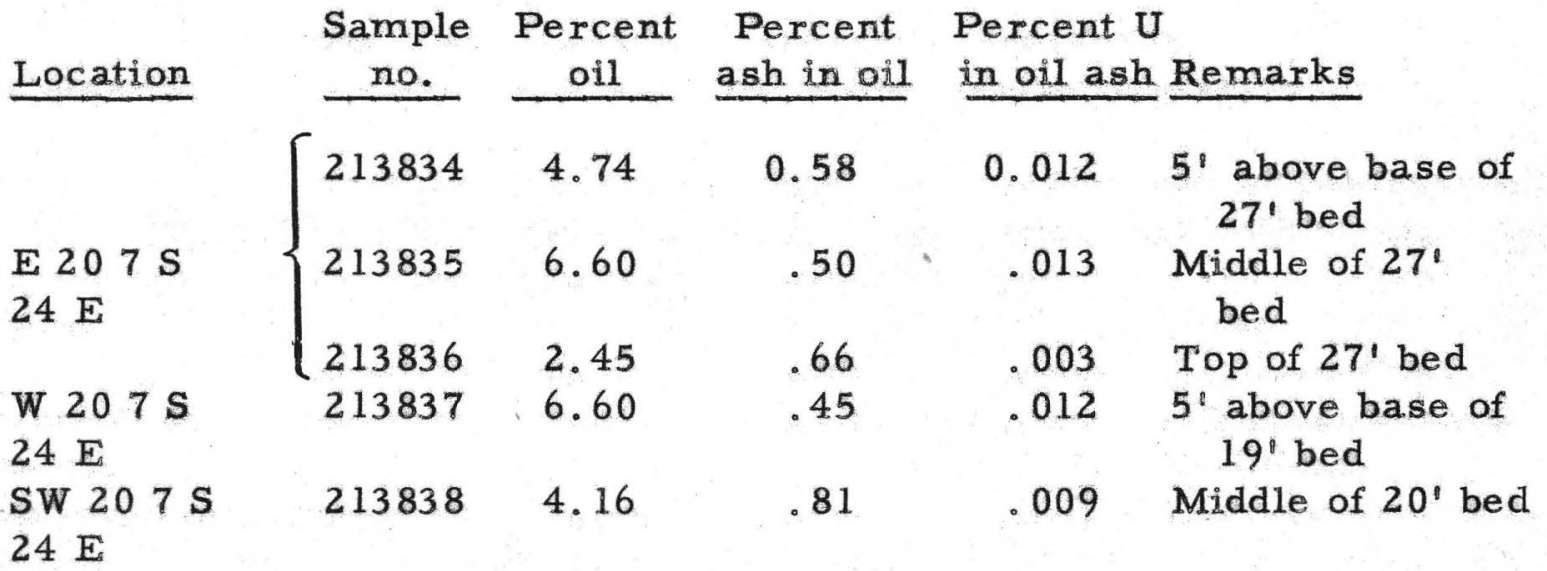




\section{New Mexico}

Santa Rosa area

Beds of asphalt-bearing sandstone in the Santa Rosa sandstone of Triassic age crop out in northern Guadalupe County at the abandoned quarries of the New Mexico Construction Company, about 10 miles north of Santa Rosa. The asphalt occurs in the upper and middle sandstone members of the Santa Rosa sandstone. The Santa Rosa sandstone is overlain unconconformably by the Chinle formation, also of Triassic age, and underlain unconformably by the San Andres limestone of Permian age. The rocks dip generally southwestward at a low degree. The average thickness of the Santa Rosa sandstone is 250 feet. The beds of asphalt-bearing sandstone range in thickness from 4 to 18 feet in quarry exposures, and to a maximum of 100 feet in a core hole. The total reserves of asphaltbearing sandstone are 102,000,000 tons (Gorman and Robeck, 1946). There has been no production since 1939.

Samples collected in the Santa Rosa area

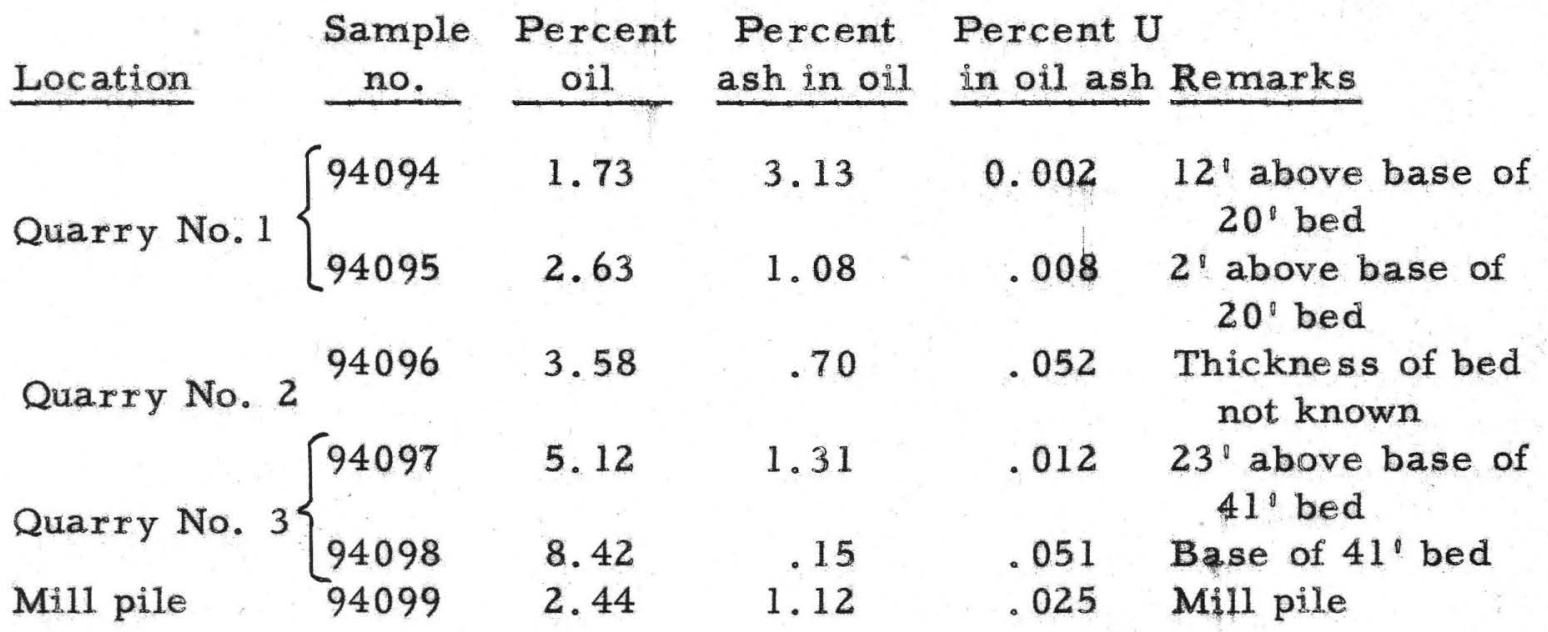




\section{Texas}

\section{Uvalde area.}

Large deposits of asphalt-bearing limestone in the Anacacho limestone of Late Cretaceous age crop out in an area of about 60 square miles in the vicinity of Blewett in the western part of Uvalde County. The uranium content of the asphalt is exceptionally low, ranging from 0.001 to 0.004 percent and averaging 0.002 percent in the ash of the extracted oil.

The asphalt impregnates porous coquina beds which range in thickness from 10 to 135 feet in quarry exposures and are as much as 200 feet thick in drill holes. The distribution of the asphalt in the limestone is highly variable both horizontally and vertically. Two companies were quarrying the rock in 1953. The total reserves of minable asphalt-bearing limestone in the area are about $340,000,000$ tons (Gorman and Robeck, 1945).

Samples collected in the Uvalde area

\begin{tabular}{|c|c|c|c|c|c|}
\hline Location & $\begin{array}{c}\text { Sample } \\
\text { no. } \\
\end{array}$ & $\begin{array}{l}\text { Percent } \\
\text { oil } \\
\end{array}$ & $\begin{array}{c}\text { Percent } \\
\text { ash in oil } \\
\end{array}$ & $\begin{array}{l}\text { Percent U } \\
\text { in oll ash } \\
\end{array}$ & Remarks \\
\hline $\begin{array}{l}\text { Original No. } \\
1 \text { Quarry }\end{array}$ & 99579 & 12.160 & 0.28 & 0.002 & $\begin{array}{l}\text { Thickness of bed } \\
\text { not known }\end{array}$ \\
\hline South Quarry & 99580 & 8.02 & .63 & .002 & Quarry dump \\
\hline Gato Quarry & $\left\{\begin{array}{l}99581 \\
99582\end{array}\right.$ & $\begin{array}{l}5.75 \\
7.53\end{array}$ & .22 & $\begin{array}{l}.002 \\
.002\end{array}$ & $\begin{array}{l}\text { Mill concentrate } \\
\text { Top of } 80^{\circ} \text { bed }\end{array}$ \\
\hline $\begin{array}{l}\text { East end of } \\
\text { Gato Quarry }\end{array}$ & 99583 & 8.82 & .42 & .001 & Base of $80^{\circ}$ bed \\
\hline $\begin{array}{l}\text { West end of } \\
\text { Gato Quarry }\end{array}$ & 99584 & 10.42 & .37 & .002 & Base of $80^{\circ}$ bed \\
\hline $\begin{array}{l}\text { White }{ }^{\circ} \text { Uvalde } \\
\text { Mine Quarry }\end{array}$ & 999585 & 9.18 & .43 & .002 & $\begin{array}{l}18^{\circ} \text { above base of } \\
40^{\prime} \text { bed }\end{array}$ \\
\hline & 99586 & 7.65 & .55 & .001 & Base of $40^{\circ}$ bed \\
\hline White's Mine & $\left\{\begin{array}{l}99587 \\
99589 \\
99590\end{array}\right.$ & $\begin{array}{l}5.54 \\
8.93 \\
9.39\end{array}$ & $\begin{array}{l}.22 \\
.69 \\
.35\end{array}$ & $\begin{array}{l}.002 \\
.004 \\
.004\end{array}$ & $\begin{array}{l}\text { Mill concentrate } \\
\text { Middle of } 130^{\circ} \text { bed } \\
\text { Upper part of } 130^{\circ} \\
\text { bed }\end{array}$ \\
\hline
\end{tabular}




\section{Oklahoma}

The 17 asphalt deposits examined in Okłahoma occur in formations of Ordovician, Pennsylvanian, and Permian age. One of the deposits occurs in limestone; the rest occur in quartzose sandgtones. Most of the areas examined do not contain above-average amounts of uranium in the ash of the extraeted oil. Only the Sulphur, Cameron, and Ada areas yielded samples eontaining appreciable amounts of ura nium. Asphaltbearing limestone from the Dougherty area is exceptionally low in uranium.

\section{Sulphur area}

Asphalt-bearing sandstone and limestone beds crop out about 5 miles south of the town of Sulphur, Murray County, and the deposits cover an area of about 1 square mile. Most of the asphalt oceurs in the Oil Creek formation of Ordovieian age. The major structure in the a rea is a highly faulted northeastward-trending anticline. Surface exposures of asphaltbearing sandstone range in thiekness from about 6 to 90 feet, although there are few places where an asphalt-bearing bed is fully exposed. A well drilled in the northern part of the area is reported to have penetrated 242 feet of asphalt-bearing sandstone beginning at a depth of 101 feet (Gorman and others, 1944). There was some production of asphalt in 1953 by the Southern Rock Asphalt Sand Mines company. 
Samples collected in the Sulphur area

\begin{tabular}{|c|c|c|c|c|c|}
\hline Location & $\begin{array}{c}\text { Sample } \\
\text { no. }\end{array}$ & $\begin{array}{c}\text { Percent } \\
\quad \text { oil } 1 \\
\end{array}$ & $\begin{array}{c}\text { Percent } \\
\text { ash in oil }\end{array}$ & $\begin{array}{l}\text { Percent } \\
\text { in oil ash }\end{array}$ & Remarks \\
\hline & 99607 & 7.95 & 0.41 & 0.004 & $\begin{array}{l}\text { West end of Barnes } \\
\text { No. } 1 \text { Pit; middle } \\
\text { of } 6^{\circ} \text { bed }\end{array}$ \\
\hline $\begin{array}{l}\mathrm{SE} 151 \mathrm{~S} \\
3 \mathrm{E}\end{array}$ & 99608 & 3.62 & .71 & .039 & $\begin{array}{l}\text { North end of Pit No. } \\
80 \text {; upper part of } \\
60^{\circ} \text { bed }\end{array}$ \\
\hline & 201552 & 4.80 & .72 & .032 & $\begin{array}{l}\text { South end of Pit No. } \\
80 \text {; upper part of } \\
60^{\circ} \text { bed }\end{array}$ \\
\hline $\begin{array}{l}\text { NE.22 } 1 \mathrm{~S} \\
3 \mathrm{E}\end{array}$ & 201553 & 6.05 & .41 & .001 & $\begin{array}{l}\text { Northeast end of } \\
\text { Barnes No. } 2 \text { Pit; } \\
\text { middle of } 18^{\prime} \text { bed }\end{array}$ \\
\hline $\begin{array}{l}\mathrm{SW} 151 \mathrm{~S} \\
3 \mathrm{E}\end{array}$ & 201555 & 3.05 & .78 & .22 & $\begin{array}{l}\text { Rock Asphalt Sand } \\
\text { Mines Quarry; mid - } \\
\text { dle of } 90^{\prime} \text { bed }\end{array}$ \\
\hline $\begin{array}{l}\text { NW } 221 \mathrm{~s} \\
3 \mathrm{E}\end{array}$ & $\begin{array}{l}201556 \\
201557\end{array}$ & $\begin{array}{l}4.00 \\
2.44\end{array}$ & $\begin{array}{r}1.12 \\
.61\end{array}$ & $\begin{array}{l}.002 \\
.004\end{array}$ & $\begin{array}{l}\text { Griffith No. } 1 \text { Pit; } \\
\text { middle of } 20^{\prime} \text { bed } \\
\text { East Kirby Pit; thick- } \\
\text { ness of bed not } \\
\text { known }\end{array}$ \\
\hline
\end{tabular}

Cameron area

Asphalt-bearing sandstone is exposed in an abandoned quarry or prospect pit just across the road from Cameron College, Comanche County. The bed is 5 feet thick and lies between beds of barren sandstone in the Wichita formation of Permian age. The lateral extent of the asphalt-bearing bed is not known, but it probably does not extend over a very large area.

Samples collected in the Cameron area

$\underline{\text { Location }}$

Sample Percent Percent Percent U

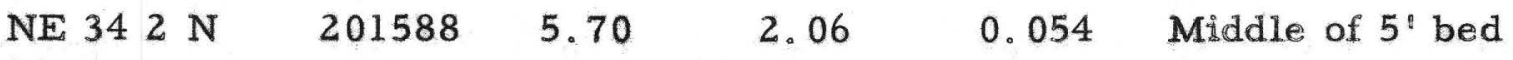

$12 \mathrm{~W}$ 
Other areas

Deposits of asphalt were also examined in 15 other areas in Oklahoma, but most of the samples from these deposits contained relatively small amounts of uranium. A sample representing a 1 -foot bed of asphalt-bearing sandstone in the Ada area, Pontotoc County, contained 0.042 percent uranium in the ash of the extracted oil. The Dougherty area, Murray County, contains large deposits of asphalt-bearing limestone in the Viola limestone of Ordovician age (Gorman and Flint, 1944), but the uranium content of the asphalt is exceptionally low. Asphaltbearing sandstones of Pennsylvanian age were sampled in the Ada and Fitzhugh areas (Ada formation), Pontotoc County; in the Bratcher and Morgan areas (Deese formation), Carter County; and in the Woodford area (Springer formation), Carter County. Asphalt-bearing sandstones in the Wichita formation of Permian age were sampled in the Parker, Elgin, Frisco Creek, and Lawton Township areas, Comanche County; in the Velma area, Stephens County; in the Baseline area, Garvin County; in the Lone Grove and Oil City areas, Carter County; and in the Asphaltum area, Jefferson and Stephens Counties. The Ada, Bratcher, Woodford, and Asphaltum areas probably contain large reserves of asphalt-bearing sandstone; the other areas contain only small reserves.

Samples collected in the Dougherty area

$$
\text { Sample Percent Percent Percent U }
$$

Location no. oil ash in oil in oil ash Remarks

SE 25 IS 2E $\begin{array}{llrrl}99599 & 3.92 & 0.42 & 0.001 & 40^{\prime} \text { above base of } 80^{\circ} \mathrm{bed} \\ 99601 & 3.63 & .52 & .001 & 75^{\circ} \text { above base of } 80^{\circ} \mathrm{bed} \\ 99603 & 2.00 & 1.04 & .001 & \text { Upper part of } 100^{\prime} \text { bed }\end{array}$


Samples collected in the Ada area

\begin{tabular}{|c|c|c|c|c|c|}
\hline Location & $\begin{array}{c}\text { Sample } \\
\text { no. } \\
\end{array}$ & $\begin{array}{l}\text { Percent } \\
\text { oil } \\
\end{array}$ & $\begin{array}{r}\text { Percent } \\
\text { ash in oil }\end{array}$ & $\begin{array}{l}\text { Percent U } \\
\text { in oil ash }\end{array}$ & Remarks \\
\hline NW6 $3 \mathrm{~N} 6 \mathrm{E}$ & 99591 & 4.08 & 4.09 & 0.002 & $6^{\circ}$ above base of $16^{\prime} \mathrm{bed}$ \\
\hline NW 13 N $5 E$ & 99592 & 1.87 & .81 & .005 & Lower part of $12^{\circ}$ bed \\
\hline SW19 4 N $6 E_{1}$ & 99593 & 3.00 & 2.13 & .042 & $1^{9}$ bed \\
\hline NW36 $4 \mathrm{~N} 6 \mathrm{E}$ & 99594 & 4.20 & .75 & .007 & $\begin{array}{l}\text { Thickness of bed not } \\
\text { known }\end{array}$ \\
\hline
\end{tabular}

Samples collected in the Fitzhugh area

$\begin{array}{llllll}323 \mathrm{~N} \mathrm{FE} & 99596 & 1.68 & 1.85 & .003 & \begin{array}{c}\text { Thickness of bed not } \\ \text { known }\end{array} \\ 52 \mathrm{~N} \mathrm{5E} & 99597 & 1.02 & 2.16 & .001 & 2^{3} \text { bed }\end{array}$

Samples collected in the Bratcher area

NW16 4S 1E 214 S IE $\left\{\begin{array}{lllll}201571 & 9.58 & .77 & .015 & \text { Quarry dump } \\ 200933 & 7.29 & .91 & .005 & \text { Upper part of 22' bed } \\ 201572 & 9.30 & .09 & .003 & \text { Quarry dump }\end{array}\right.$

Sample collected in the Morgan area

NE14 5S 1E $\quad 201569 \quad 5.71 \quad .76 \quad .005 \quad$ Middle of 6 ' bed

Samples collected in the Woodford area

33S 1W $\left\{\begin{array}{rrrrl}201574 & 2.26 & 6.49 & .017 & \text { Middle of } 60^{\circ} \mathrm{bed} \\ 201575 & 4.44 & 6.60 & .010 & \text { Middle of } 40^{\circ} \mathrm{bed} \\ 201576 & 1.66 & 1.77 & .004 & \text { Prospect dump }\end{array}\right.$

Sample collected in the Parker area

SW15 4N 11W $201593 \quad 2.16 \quad 1.62 \quad 004 \quad 2^{\prime}$ bed

Sample collected from the Elgin area

$\begin{array}{lllll}\text { SW26 } 4 \mathrm{~N} 11 \mathrm{~W} & 201592 & 1.76 & 1.98 & .006 \quad \text { Upper part of } 5^{\prime} \text { bed }\end{array}$

Samples collected from the Frisco Creek area

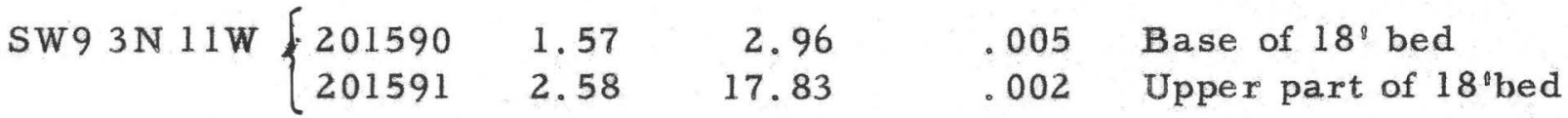


Sample collected in the Lawton Township area

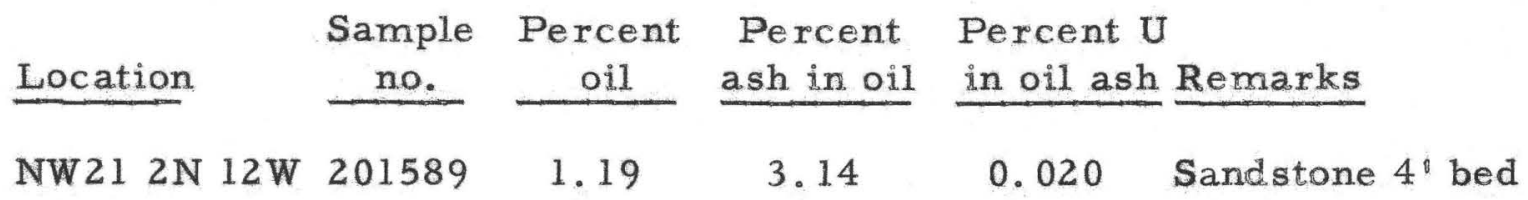

Sample collected in the Velma area

$\begin{array}{lllll}\text { SE36 1S 5W } & 201586 & .94 & 1.68 & .001 \quad \begin{array}{c}\text { Thickness of bed } \\ \text { not known }\end{array}\end{array}$

Samples collected in the Baseline area

$\begin{array}{lrrrrl}\text { E36 1N 3W } & 201558 & .79 & 2.71 & .007 & 4^{\prime} \text { bed } \\ \text { NW } 171 \mathrm{~N} \mathrm{3W} & 201560 & 1.17 & 2.98 & .002 & \text { Lower part of } 5^{\circ} \text { bed }\end{array}$

Sample collected in the Lone Grove area

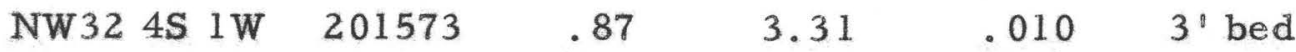

Sample collected in the Oil City area

$\begin{array}{llllll}213 \mathrm{~S} 2 \mathrm{~W} & 201577 & 12.28 & 4.49 \quad .002 \quad \text { Lower part of } 8^{\prime} \text { bed }\end{array}$

Samples collected in the Asphaltum area

\begin{tabular}{|c|c|c|c|c|c|}
\hline \multirow[t]{3}{*}{$\mathrm{SE} 233 \mathrm{~S} 5 \mathrm{~W}$} & 201579 & 4.27 & 1.64 & .006 & Lower part of $30^{\circ} \mathrm{bed}$ \\
\hline & 201580 & 7.47 & .66 & .002 & Middle of $30^{\prime}$ bed \\
\hline & 201581 & 9.72 & 2.08 & .006 & Upper part of $30^{\circ} \mathrm{bed}$ \\
\hline U & 200934 & 8.07 & .97 & .013 & $\begin{array}{l}20^{\circ} \text { above base of } 30^{\circ} \\
\text { bed }\end{array}$ \\
\hline $7114 \mathrm{~S}$ & 201584 & 1.21 & 2.64 & .006 & $3^{\prime}$ bed \\
\hline
\end{tabular}




\section{Missouri}

The asphalt deposits in all five areas examined in Vernon County, Missouri, occur in one or more lenticular sandstone beds in the Cherokee shale of Pennsylvanian age. These sandstone beds probably correlate with the Bartlesville sand of the midcontinent oil fields, which is the surface equivalent of the Bluejacket sandstone in Oklahoma, and the probable equivalent of the Graydon sandstone in Missouri (Dane and Hendricks, 1936, p. 312, and Greene and Pond, 1926, p. 45). The rock containing the asphalt is mainly a fine-grained, micaceous, quartzose sandstone. Where asphalt is absent, the sandstone is quite friable. Large reserves of asphalt-bearing sandstone extend under shallow cover over a wide area in Vernon County. Most of the samples collected in Missouri did not contain above average amounts of uranium. One sample from the Ellis area, however, yielded 0.40 percent uranium in the ash of the extracted oil.

\section{Ellis area}

Asphalt-bearing sandstone is exposed in an abandoned water-filled quarry at Ellis, Vernon County. The quarry is about 160 feet wide and 265 feet long, and the exposed thickness of the asphalt-bearing bed ranges from 15 to 30 feet. The base of the bed is covered by water in the quarry; the top is obscured by soil. The quarry has been operated recently enough so that the asphalt-bearing rock is not greatly weathered. 
Samples collected in the Ellis area

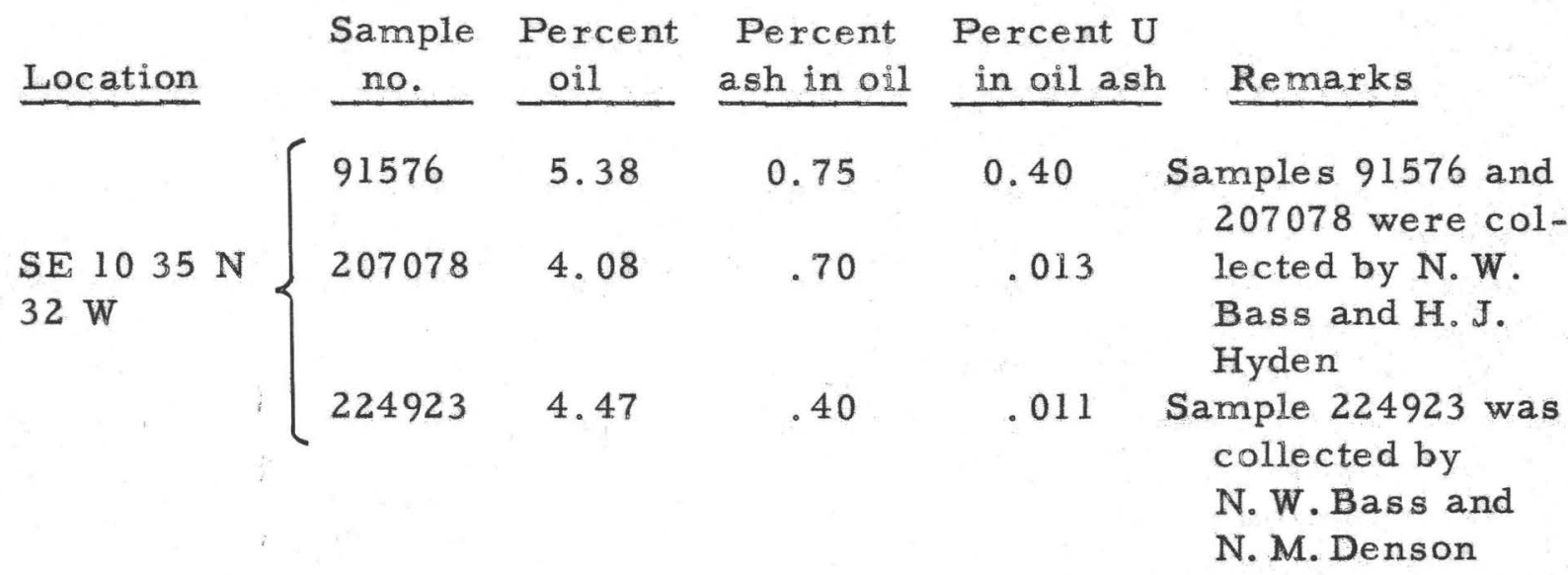

Other areas

Deposits of asphalt-bearing sandstone were also examined in the Deerfield, Sheldon East, Sheldon North, and Dry Wood Creek areas, Vernon County. Exposed asphalt-bearing beds in these areas range from 1 to 9 feet in thickness. The exposures in the Deerfield, Sheldon East, and Dry Wood Creek areas are in abandoned quarries, indicating some production of asphalt-bearing rock in the past. The exposure in the Sheldon North area is in a road cut.

Samples collected in the Deerfield area

\begin{tabular}{|c|c|c|c|c|c|}
\hline Location & $\begin{array}{c}\text { Sample } \\
\text { no. } \\
\end{array}$ & $\begin{array}{c}\text { Percent } \\
\quad \text { oil } \\
\end{array}$ & $\begin{array}{c}\text { Percent } \\
\text { ash in oil }\end{array}$ & $\begin{array}{l}\text { Percent } \\
\text { in oil ash }\end{array}$ & Remarks \\
\hline \multirow{7}{*}{$\begin{array}{l}\text { SW } 635 \mathrm{~N} \\
32 \mathrm{~W}\end{array}$} & 219691 & 4.73 & 0.44 & $0.010 \quad 1$ & $l^{\prime}$ above base of $9^{\prime}$ bed \\
\hline & 219692 & 4.65 & .44 & $.010 \mathrm{r}$ & Upper part of $8-1 / 2$ bed \\
\hline & 219693 & 5.54 & .68 & $.006 \mathrm{I}$ & Lower part of $8-1 / 2^{\circ}$ bed \\
\hline & 219694 & 4.37 & .78 & $.003 \mathrm{I}$ & Lower part of $6^{\prime}$ bed \\
\hline & 219695 & 4.57 & .93 & .008 & Upper part of $11^{\circ} \mathrm{bed}$ \\
\hline & 219696 & 4.56 & .84 & .002 & Middle of $11^{\circ}$ bed \\
\hline & 219697 & 3.96 & 1.43 & .0021 & Lower part of $6^{\circ}$ bed \\
\hline
\end{tabular}


Samples collected in the Sheldon East ayea

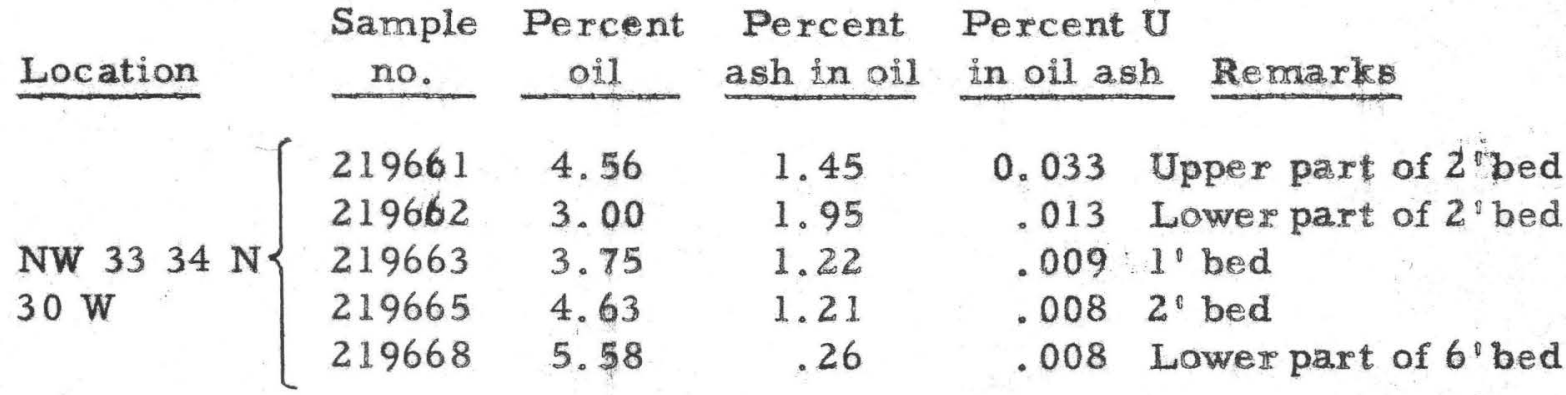

Samples collected in the Sheldon North area

\begin{tabular}{|c|c|c|c|c|c|}
\hline & 219669 & 1.58 & 1.58 & .002 & Upper part of $8^{\circ} \mathrm{b}$ \\
\hline W & 219670 & 1.12 & 1.59 & .005 & Middle of $8^{\circ}$ bed \\
\hline & & 1.60 & .65 & .006 & Lower par \\
\hline
\end{tabular}

Samples collected in the Dry Wood Creek area

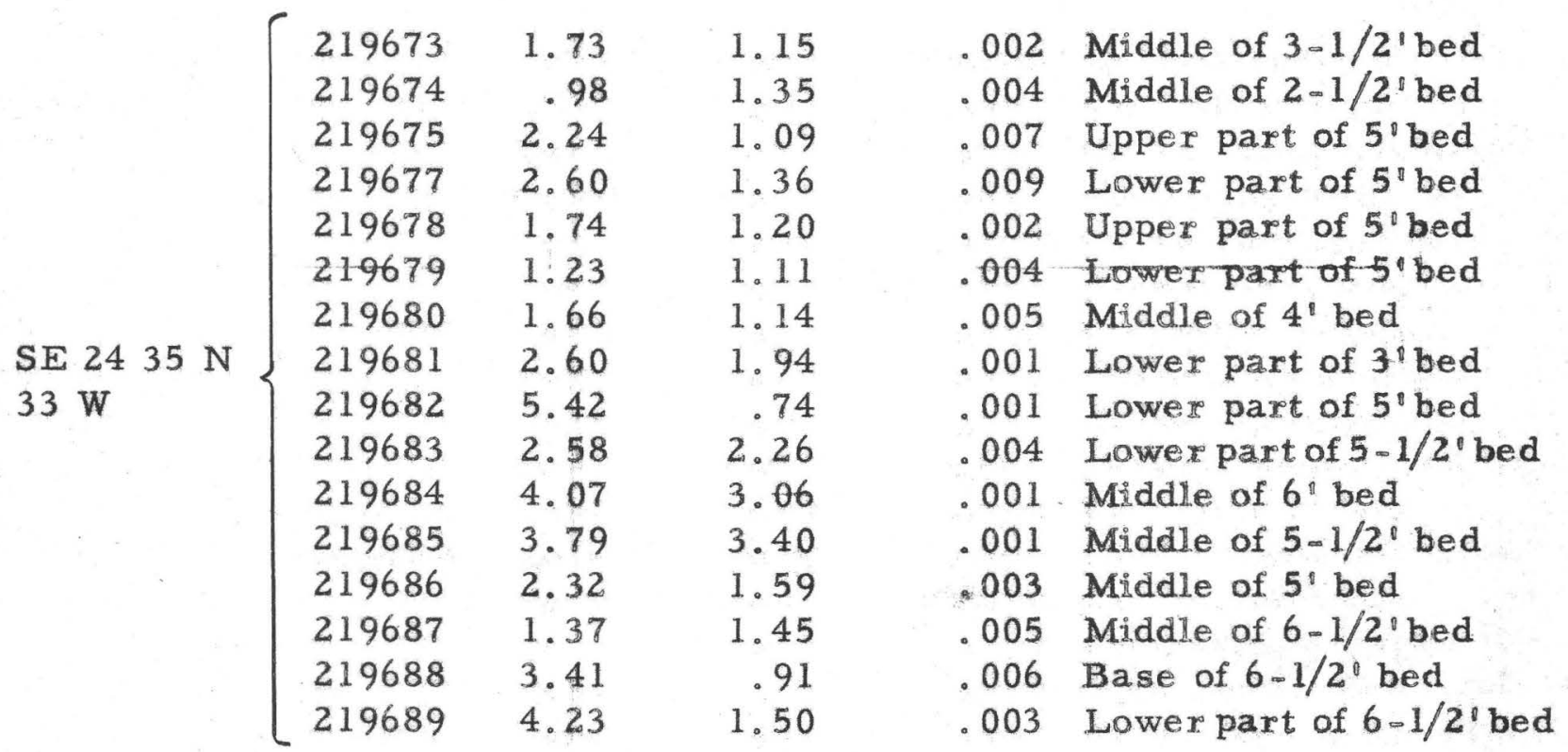




\section{LITERATURE CITED}

Bramlette, M. N., and Daviess, S. N., 1944, Geology and oil possibilities of the Salinas Valley, California: U. S. Geol. Survey Oil and Gas Inv. Prelim. Series map 24.

Cashion, W. B., and Brown, J. H., Jr., in press, Geology of the Bonanza-Dragon oil-shale area, Uintah County, Utah, and Rio Blanca County, Colorado: U. S. Geol. Survey OM 153.

Dane, C. H., and Hendricks, T. A. , 1936, Correlation of Bluejacket sand stone, Oklahoma: Am. Assoc. Petroleum Geologists Bull., v. 20, p. 312-314.

Eldridge, G. H., 1901, The asphalt and bituminous rock deposits of the United States: U. S. Geol. Survey 22d Ann. Rpt., 1900-1901, p. 209-452.

Erickson, R. L., Myers, A. T., and Horr, A. C., 1954, Association of uranium and other metals with crude oil, asphalt, and petroliferous rock: Am. Assoc. Petroleum Geologists Bull., v. 38, p. 2200-2218.

Goldschmidt, V. M., 1954, Geochemistry: London, Oxford Univ. Press.

Gorman, J. M., and Flint, G. M., Jr., 1944, Geologic map of the Dougherty asphalt area, Murray County, Oklahoma: U. S. Geol. Survey Oil and Gas Inv. Prelim. Series map 15.

Gorman, J. M., Flint, G. M., Jr., Decker, C. E., and Ham, W. E., 1944, Geologic map of the Sulphur asphalt area, Murray County, Oklahoma: U. S. Geol. Survey Oil and Gas Inv. Prelim. Series $\operatorname{map} 22$.

Gorman, J. M., and Robeck, R. C., 1945, Asphalt deposits near Uvalde, Texas: U. S. Geol. Survey open file report.

, 1946, Geology and asphalt deposits of north-central Guadalupe County, New Mexico: U. S. Geol. Survey Oil and Gas Inv. Prelim. Series map 44.

Greene, F. C., and Pond, W. F., 1926, The geology of Vernon County: Missouri Bur. Geology and Mines, v. 19, 2nd ser. 
Hares, C. J., 1917, Anticlines in central Wyoming: U. S. Geol. Survey Bull. 641J.

Holmes, C. N., Page, B. M., and Averitt, Paul, 1948, Geology of the bituminous sandstone deposits near Sunnyside, Carbon County, Utah: U. S. Geol. Survey Oil and Gas Inv. Prelim. Serìes map 86.

Holmes, C. N., Page, B. M., and Duncan, D. C.。 1951, Bituminous sandstone deposits of Point Arena, Mendocino County, California: U. S. Geol. Survey Oil and Gas Inv. Prelim. Series map 125.

Hoots, H. W., 1943, Origin, migration, and accumulation of oil in California, in Jenkins, O. P. Geologic formations and economic development of the oil and gas fields of California: California Div. Mines Bull. 118, p. 253-276.

Jamison, C. E。, 1912, The Muddy Creek oil field, Carbon County, Wyoming: Wyoming Geol. Survey Bull. 3, ser. B, p. 43-50.

Kinney, D. M., and Rominger, J. F., 1947, Pre-Tertiary geology of the Whiterocks River-Ashley Creek area, Uintah County, Utah: U. S. Geol. Survey Oil and Gas Inv。 Prelim. Series map 82.

Knappen, R.S., and Moulton, G. F., 1930, Geology and mineral resources of parts of Carbon, Big Horn, Yellowstone, and Stillwater Counties, Montana: U. S. Geol. Survey Bull. 822A.

Page, B. M., Henrickson, E。 L., Williams, M. D., and Moran, T. G., 1945a, Asphalt and bituminous sandstone deposits of part of the McKittrick district, Kern County, California: U. S. Geol. Survey Oil and Gas Inv. Prelim. Series map 35.

Page, B. M. , Williams, M. D. , Henrickson, E. L., Holmes, C. N., and Mape1, W. J., 1944, Geology of the bituminous sandstone de posits near Edna, San Luis Obispo County, California: U. S. Geol. Survey Oil and Gas Inv. Prelim. Series map 16.

1945b, Bituminous sandstone deposits near Santa Cruz County, California: U. S. Geol. Survey Oil and Gas Inv. Prelim. Series map 27.

Spieker, E. M., 1930, Bituminous sandstone near Vernal, Utah: U. S. Geol. Survey Bull. 822C. 
Taliaferre, N. L., 1943, Geologic history and structure of the central coast ranges of California, in Jenkins, O. P., Geologic formations and economic development of the oil and gas fields of California: California Div. Mines Bull. 118, p. 119-163.

Vine, J. D., and Moore, G. W., 1952, Reconnaissance for uraniumbearing carbonaceous rocks in nor thwestern Colorado, southwestern Wyoming, and adjacent parts of Utah and Idaho: U. S. Geol. Survey TEI-281, U. S. Atomic Energy Comm。, Teeh. Inf. Service, Oak Ridge.

Vine, Jo $D_{0}$, and Flege, R. F。, Jr。, 1953, Reconnaissanee during 1952, for uranium-bearing carbonaceous rocks in parts of Colorado, Utah, Idaho, and Wyoming: U. S. Geol. Survey TEI-336, U. S. Atomic Energy Comm。, Tech. Inf. Service, Oak Ridge.

Williams, M. D., and Holmes, C. No., 1945, Geology of oil-impregnated diatomaceous rock near Casmalia, Santa Barbara County, California: U. S. Geol. Survey Oil and Gas Inv. Prelim. Series map 34. 